\title{
A new kentriodontid (Cetacea: Delphinoidea) from the Middle Miocene of Hungary
}

\author{
Emese Kazár* \\ Geological Institute of Hungary, Stefánia út 14, H-1143 Budapest, Hungary
}

Received 18 February 2005, accepted 15 May 2005

Published online 02.11.2005

With 13 figures and 7 tables

Key words: Odontoceti, Kentriodontidae, Pithanodelphininae, Miocene, Sarmatian, Hungary.

\begin{abstract}
Mediocris commenticius n. gen., n. sp. is herein described as a kentriodontid dolphin from the Sarmatian (late Middle Miocene) of south Hungary, territory of the ancient Central Paratethys Sea. The type specimen is an incomplete skeleton including a distorted skull and mandibles with teeth, ear bones, elements of both flippers, and numerous vertebrae. Mediocris commenticius has a nasal bone morphology that differs from all delphinoid taxa, but is most similar to members of the Pithanodelphininae Barnes, 1985. The nasals are triangular, not inflated, have a faint anterolateral notch, and diverge posteriorly. On the basis of the nasal bone morphology, the new species shows affinities to Pithanodelphis, and is less derived than Atocetus and Sarmatodelphis. Due to the incompleteness of the cranial vertex of the type and only known skull, however, the species is only tentatively referred to the subfamily Pithanodelphininae.
\end{abstract}

Schlüsselwörter: Odontoceti, Kentriodontidae, Pithanodelphininae, Miozän, Sarmatium, Ungarn.

\section{Zusammenfassung}

Mediocris commenticius n. gen., n. sp. wird als Kentriodontide aus dem Sarmatium (spätes Mittelmiozän) von Südungarn beschrieben, aus dem Gebiet des ehemaligen zentral-paratethyschen Meeres. Der Holotypus ist ein unvollständiges Skelett; erhalten sind der zusammengepresste Schädel, Unterkiefer mit Zähnen, Gehörknochen, Knochenelemente beider Brustflossen sowie zahlreiche Wirbel. Die Morphologie der Nasale der neuen Art unterscheidet sich von allen beschriebenen Taxa der Kentriodontidae, weist aber auf Verwandtschaft mit den Pithanodelphinen hin. Die Nasalia sind dreieckig, nicht extrem vergrößert, sie haben eine schwach ausgebildete anterolaterale Kerbe und sie divergieren in caudaler Richtung. Anhand der Morphologie der Nasale steht M. commenticius der Art Pithanodelphis cornutus nahe und ist weniger stark spezialisiert als Atocetus und Sarmatodelphis. Wegen der unvollständigen Erhaltung des cranialen Vertex ist Mediocris commenticius allerdings nur mit Vorbehalt in die Unterfamilie Pithanodelphininae einzuordnen.

\section{Introduction}

In 1993, curators of the Department of Palaeontology of the Hungarian Natural History Museum managed to buy a fossil dolphin skeleton that was up for sale at a mineral fair. The beautiful though incomplete skeleton was found and collected by private collector Mr. Sándor Klaj near the village Kovácsszénája, south Hungary in 1992 (Fig. 1). He excavated the skull and the anterior part of the skeleton, and returned to the site for the remainder later in the same year. Meanwhile, other (unknown) collector(s) had visited the site and removed the middle part of the skeleton including the lumbar and anterior caudal vertebrae. These elements are apparently

\footnotetext{
* Corresponding author: e-mail: kazar@mafi.hu
} 


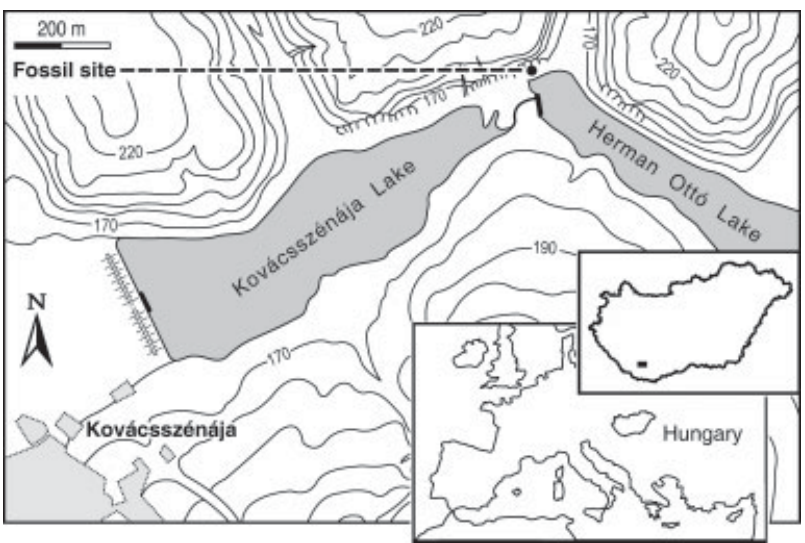

Fig. 1. Geographic map of the type locality of Mediocris commenticius n. gen. n. sp. Inserted maps: The type locality within Hungary (top), and the position of Hungary within Europe (bottom).

lost for science. A few vertebral fragments including the $7^{\text {th }}$ and $9^{\text {th }}$ thoracics were picked up by Mr. Béla Zalán who has kindly donated these elements to the Geological Museum of the Geological Institute of Hungary in 2001.

The fossil dolphin skeleton has been mentioned by Fózy (1993), Kazár \& Kordos (1999), Sütő-Szentai (2001), and Kazár (2005). Kazár (2003) provided a preliminary description and systematic evaluation in a Ph.D. thesis.

The aim of the present paper is to describe the specimen as a new genus and new species of the Kentriodontidae, and consider its taxonomic position within the family. The Kentriodontidae is used herein as a grade family, because no synapomorphies of the included taxa are known (Muizon 1988b; Fordyce \& Barnes 1994; Ichishima et al. 1994).

\section{Material and Methods}

The specimen was collected by S. Klaj and B. Zalán. Sándor Klaj secured the fragmentary elements of the skeleton and the apical rostral teeth by plaster, and fixed the cervical vertebrae by a steel rod. After the author received the specimen for study, a dental drill was used to free the bones from the embedding limy marl and the excess plaster. Both periotics and the right tympanic bulla were removed from the surrounding bones, which caused some damage to the otic regions of the skull.

Comparisons were made with the following species and specimens:

- Kentriodon pernix Kellogg, 1927 - holotype USNM 8060 and paratype USNM 10670;

- Liolithax kernensis Kellogg, 1931 - paratype USNM 11565 and hypotype USNM 10854;

- Delphinodon dividum True, 1912 - holotype USNM 7278;

- Liolithax pappus (Kellogg, 1955) - holotype USNM 15985;

- Lophocetus calvertensis (Harlan, 1842) - holotype USNM 16314 and referred specimen USNM 205297;
- Lophocetus repenningi Barnes, 1978 - holotype USNM 23886;

- Pithanodelphis cornutus (Du Bus, 1872) - holotype IRSNB 3652-M.373;

- Hadrodelphis calvertense Kellogg, 1966 (Dawson 1996a) referred specimen CMM-V-11;

- Macrokentriodon morani Dawson, 1996 - holotype CMM$\mathrm{V}-15$;

- Belonodelphis peruanus Muizon, 1988 - holotype MNHN PPI 231;

- Atocetus iquensis Muizon, 1988 - holotype MNHN PPI 113 and referred specimens MNHN PPI 114-116;

- "Champsodelphis" fuchsii Brandt, 1873 - holotype NHMW 1859.XXVII.6 and referred specimens MBT 14943, 15001, 15029;

- Sarmatodelphis moldavicus Kirpichnikov, 1954 - holotype UBFG.628;

- Delphinodon(?) carniolicus (Gorjanović-Kramberger, 1892) Kellogg, 1925 - holotype HPM 1.194/43 and referred specimens HPM 1.193/32.1-3. Comparisons of all other species assigned to the family Kentriodontidae are based on the original descriptions and illustrations.

The periotics MÁFI V.23106, V.23107, V.23108, and the tympanic bullae MÁFI V.23104, V.23105 from Danitz-puszta are casts. Measurements were taken on the original periotic and tympanic bones loaned from the private collections of Mr. Zoltán Evanics and Mr. Roland Molnár.

The terminology for cranial and postcranial anatomy follows Flower (1870), Fraser \& Purves (1960), and Rommel (1990); terminology of the ear bones is derived from Kasuya (1973), Barnes \& Mitchell (1984), and Luo \& Marsh (1996). Measurements were taken with the same digital caliper.

Institutional Abbreviations - CMM, Calvert Marine Museum, Maryland; HPM, Hrvatski Prirodoslovni Muzej (Croatian Natural History Museum), Zagreb; IRSNB, Institut Royal des Sciences Naturelles de Belgique, Bruxelles; MÁFI, Magyar Állami Földtani Intézet (Geological Institute of Hungary), Budapest; MBT, Musée "Bassin de Transylvanie", Université "Babeş-Bolyai", Cluj-Napoca; MNHN, Muséum national d'Histoire naturelle, Paris; MTM, Magyar Természettudományi Múzeum (Hungarian Natural History Museum), Budapest; NHMW, Naturhistorisches Museum Wien, Vienna; UBFG, Faculty of Geology and Geophysics, University of Bucharest; USNM, National Museum of Natural History, Washington D.C.

\section{Systematic Paleontology}

Order

Suborder

Cetacea Brisson, 1762

Superfamily

Family

Odontoceti Flower, 1867

Subfamily

oidea Gray, 1821

Kentriodontidae Slijper, 1936

?Pithanodelphininae Barnes, 1985

(= Pithanodelphinae, justified emendation by Rice 1998)

\section{Mediocris n. gen.}

Derivation of name: Mediocris, Latin for middling, average, referring to the lack of extremes in the size and morphological characteristics of the new genus.

Type species: Mediocris commenticius n. $\mathrm{sp}$.

Diagnosis: As for the species. 


\section{Mediocris commenticius $\mathbf{n}$. $\mathbf{s p}$.}

2003 Kentriodontidae n. g. n. sp. - Kazár: 190-199, 285301, Pls 19-21.

Derivation of name: From the Latin commenticius $=$ fabulously ideal, which reflects the author's enthusiasm about the new species.

Holotype: MTM V.93.2, skull and mandibles with approx. 132 in situ or attached teeth, right periotic, right tympanic (left tympanic unprepared), all seven cervical vertebrae, eight thoracic and two ?lumbar vertebrae, 17 caudal vertebrae, fragments of first and second ribs, scapular fragments, both humeri, incomplete radii and ulnae; a number of carpals, metacarpals and phalanges; MÁFI V.21681, left periotic and stapes; MÁFI V.21682, $7^{\text {th }}$ and $9^{\text {th }}$ dorsal vertebrae and vertebral fragments. All elements of the same individual.

Type locality: $46^{\circ} 11^{\prime} 8^{\prime \prime} \mathrm{N}$ and $18^{\circ} 07^{\prime} 25^{\prime \prime} \mathrm{E}$ GPS at $170 \mathrm{~m}$ above sea level, calcareous marl rocks exposed northeast of the village Kovácsszénája in the Mecsek Mountains, to the north of the city Pécs, south Hungary (Fig. 1).

Formation and age: The age of the embedding calcareous marl is Sarmatian (Bohn-Havas 2001; Szegó \& SzuromiKorecz 2001), late Middle Miocene (12.7-11.6 Ma according to Harzhauser \& Piller 2004). The cliff exposes 15 meters of soft, porous limestone of the Kozárd Formation (Barabás 2001) with abundant mollusk fauna. The only layer significantly differing from the rest of the column is the $65 \mathrm{~cm}$ thick bed that hosted the holotype skeleton. It is a finely laminated calcareous marl with well-preserved skeletons of small fish and sparse mollusk remains (Fig. 2).

Referred specimens: Pécsvárad (Hungary) - MTM V.60.707, right humerus. Danitz-puszta (Hungary) - MÁFI V.23104, left tympanic (cast); MÁFI V.23105, left tympanic (cast); MÁFI V.23106, left periotic (cast); MÁFI V.23107, right periotic (cast); MÁFI V.23108, left periotic (cast); MÁFI V.23123, left periotic; MÁFI V.21674, fragment of ulna; and about 20 humeri in private collections.

Diagnosis: Kentriodontid having the following unique set of characters: rostral length about two-thirds of condylobasal length; nasals triangular with a faint anterolateral notch, not inflated, and diverging posteriorly; maxilla and premaxilla of the same width at the level of the antorbital notch; periotic broad with a convex dorsal surface and short anterior process; number of teeth ca. 37-39 in each row; humeral shaft not widened distally and slightly arched.

Mediocris commenticius differs from Kentriodon Kellogg, 1927, Delphinodon dividum, Macrokentriodon morani, Kampholophos serrulus Rensberger, 1969, and Rudicetus squalodontoides (Capellini, 1878) in lacking a tabular cranial vertex. The new species differs from Liolithax pappus, Lophocetus calvertensis, Hadrodelphis calvertense, and Lophocetus repenningi in having nasals not constricted laterally. It differs from Belonodelphis peruanus in having a shorter rostrum, a more circular articular facet of the posterior process of the periotic, which lies in the horizontal plane in contrast to the Peruvian species. Mediocris commenticius differs from Macrokentriodon morani, Liolithax pappus, Hadrodelphis calvertense and Delphinodon(?) carniolicus in its much smaller skull size and/ or smaller teeth. Mediocris commenticius differs from Incacetus broggi in that the tympanic lacks a posterolateral bifurcation of the medial furrow. The new species differs from Liolithax kernensis in having a shorter anterior process and a larger pars cochlearis of the periotic.

Mediocris commenticius differs from Atocetus nasalis (Barnes, 1985) and A. iquensis in the smaller relative size of its nasals, in the lesser width of its premaxillae at the level of the antorbital notches, from $A$. nasalis, $A$. iquensis, and "Champsodelphis" fuchsii in having more compact periotic with a mediolaterally deeper cochlear part and a shorter anterior process. It differs moreover from A. iquensis and

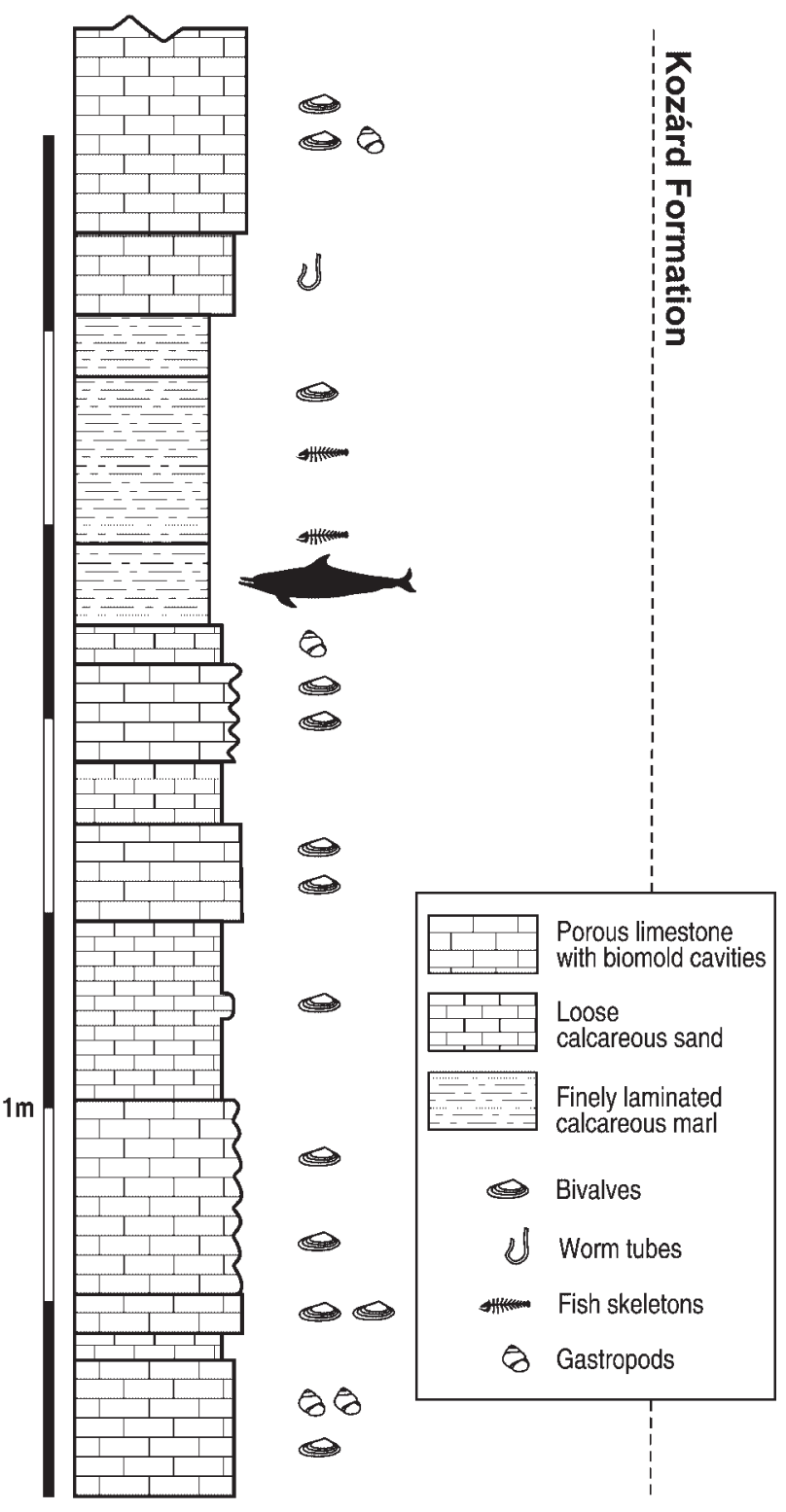

Fig. 2. Lithological section of the type locality of Mediocris commenticius n. gen. n. sp. at Kovácsszénája (south Hungary). The dominant macrofaunal elements are indicated on the right of each bed.

"Champsodelphis" fuchsii in having larger, more elongated humeri, where the anteroposterior length of the neck is only slightly smaller than that of the distal epiphysis. The new species differs from Pithanodelphis cornutus in having more elongated nasals with an almost flat dorsal surface and a less expressed anterolateral notch. Mediocris commenticius differs from Sarmatodelphis moldavicus and Leptodelphis stavropolitanus Kirpichnikov, 1954 in that the maxillae do not reach the midline of the skull posteriorly. It differs moreover from L. stavropolitanus in having a longer rostrum, and having premaxillae that are not wider than the maxillae at the level of the antorbital notches.

Description: Skull (Table 1, Figs 3, 4) - The skull is distorted; the braincase being flattened and twisted to the left. The basicranium is in large part covered by the left mandibular ramus and a mass of fractured bone. The right side of the skull posterior to the antorbital notches is 
pressed into the braincase and largely fractured in its posterior part. The right nasal is crushed into the braincase. The apex of the rostrum is missing.

The skull is larger than those of the species in the genera Kentriodon, Delphinodon, Atocetus and Pithanodelphis, but considerably smaller than the skulls of the large kentriodontid species such as Macrokentriodon morani or Hadrodelphis calvertense.

Because of the preservational state of the skull it is uncertain whether or not the skull exhibits cranial asymmetry. Posterior to the antorbital notches, the premaxillae and the nares seem to be deflected to the left, however, the entire skull is flattened towards the left. The two nasals are of the same size. It seems likely that the right premaxilla terminates more posteriorly than the left one, but the right premaxilla is fractured in its posteriormost part. As a conclusion, the skull of Mediocris commenticius is either symmetrical, or only slightly asymmetrical.

Maxilla - The rostrum is dorsoventrally deep throughout its length, deepest in the middle, as in Delphinodon, Kampholophos, and Atocetus. The dorsal contour of the rostrum is almost straight, delicately convex in the middle. This is similar in Kentriodon pernix, Hadrodelphis calvertense, Atocetus and some other kentriodontids, and differs from the rostrum profile of Lophocetus repenningi and Liolithax pappus, which have their rostra slightly curved dorsally. The rostrum has the shape of a long and narrow triange in dorsal view.

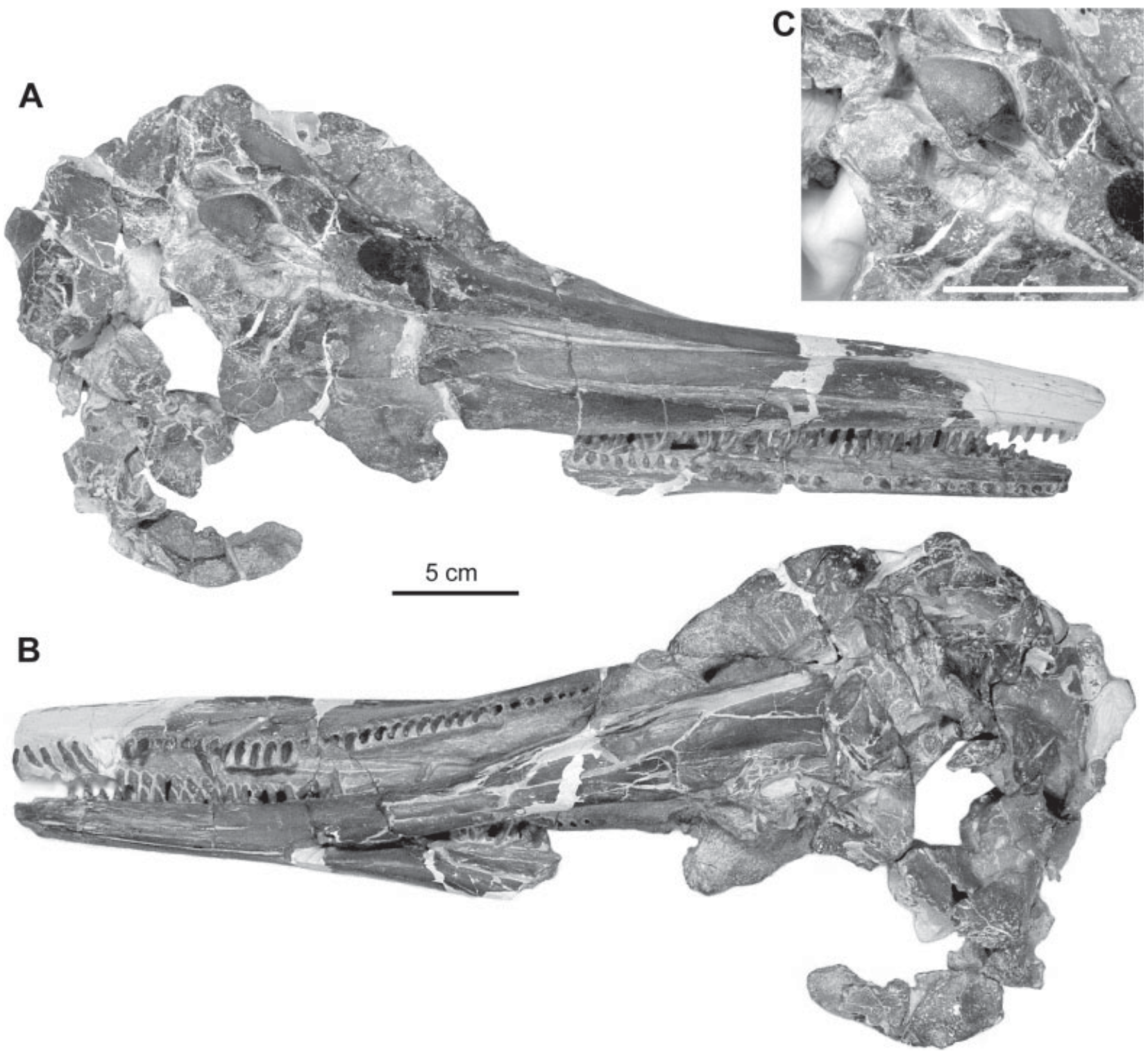

Fig. 3. Mediocris commenticius n. gen. n. sp. from Kovácsszénája, Hungary. A - dorsal view, B - ventral view of holotype skull, MTM V.93.2; C - Close-up of the nasal bones in dorsal view. 
The maxillae are approximately of the same width as the premaxillae at the level of the antorbital notches. Posteriorly the maxillae become slightly broader than the premaxillae. There is one anterior maxillary foramen on each side, which is $17 \mathrm{~mm}$ posterior to the antorbital notch on the better preserved right side. No posterior maxillary foramen is preserved. On the dorsal surface of the antorbital process the maxilla forms a small maxillary crest. It slopes medially and is elevated laterally, so that the underlying frontal and lacrimal are exposed.

The posterior margin of the maxilla is in direct contact with the occipital, and its posterior border turns up to form a nuchal crest with the occipital. Posteromedially the maxilla contacts the posterolateral corner of the nasal. The exact arrangement of bones on the cranial vertex is unclear, nevertheless it is certain that the two max- illae did not contact behind the nasals, and they approached the midline of the skull to a lesser degree than in Pithanodelphis and Atocetus. The posteromedial lobe of the maxilla bears a small, triangular depressed area, which is delimited from the rest of the bone by a faint crest. The triangular depression is similar to, but less expressed than in Atocetus iquensis and Sarmatodelphis moldavicus.

Ventrally, an elliptical sinus includes the ventral infraorbital foramina. The palatal surface is narrow and convex. The tooth rows of the upper jaw run nearly parallel to the border of the maxilla. Posteriorly the tooth rows run nearly horizontally and turn dorsally caudal to the seventh tooth from posterior. At the anterior extremity of the rostrum, the alveolar rows are very close together. At their posterior ends, they are $50.5 \mathrm{~mm}$ apart (measured on the palatal surface; $\pm 0.5 \mathrm{~mm}$ ).

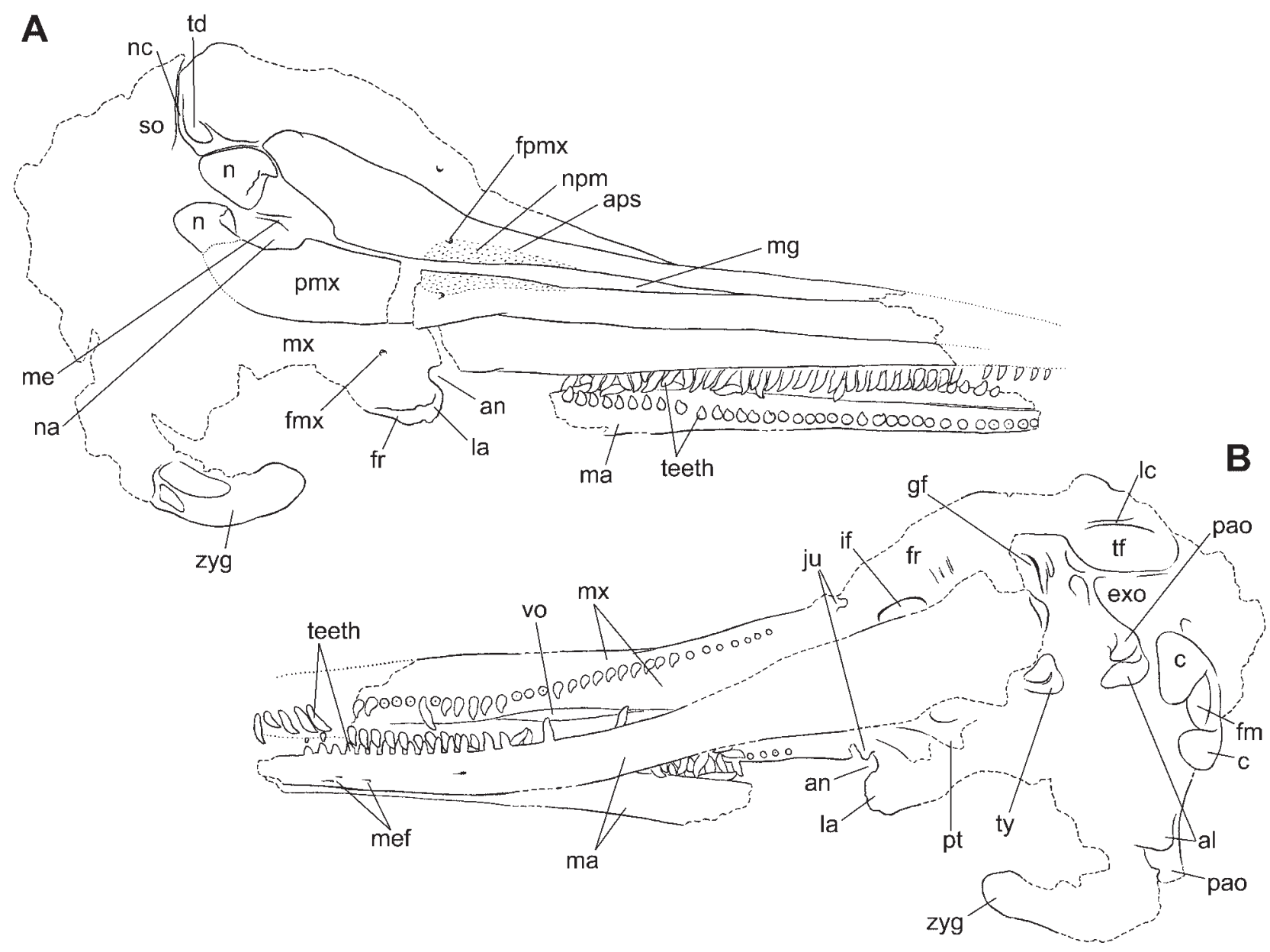

Fig. 4. Mediocris commenticius n. gen. n. sp. from Kovácsszénája, Hungary. A - dorsal view; B - ventral view of holotype skull, MTM V.93.2. Without scale. Abbreviations: al - alar process of basioccipital; an - antorbital notch; aps - anteromedial premaxillary sulcus; c - occipital condyle; exo - exoccipital; fm - foramen magnum; fmx - anterior maxillary foramen; fpmx - premaxillary foramen; fr - frontal; gf - glenoid fossa; if - ventral infraorbital foramina; ju - jugal; la - lacrimal; lc - lambdoid crest; ma - mandibles; me - mesethmoid; mef - mental foramina; mg - mesorostral gutter, mx - maxilla; n - nasal; na - naris; nc - nuchal crest; npm - nasal plug muscle attachment site; pao - paroccipital process of exoccipital; pmx - premaxilla; pt - pterygoid; so - supraoccipital; td - triangular depression of maxilla; tf - temporal fossa; ty - left tympanic bulla; vo - vomer; zyg - zygomatic process of squamosal. 
Premaxilla - There is no deep, longitudinal groove at the suture of the maxilla and the premaxilla. These two bones are of the same breadth at the base of the rostrum. The premaxillary foramina are $7 \mathrm{~mm}$ posterior to a transverse line connecting the antorbital notches, and approximately equidistant between the medial and lateral premaxillary margins. Anterior to the antorbital notch, the premaxilla is slightly constricted from lateral. The antorbital notch is wellmarked and U-shaped.

The mesorostral gutter was partially open. The premaxillae probably touched each other in the area between the premaxillary foramina and the narial openings. The mesorostral canal starts to open $40 \mathrm{~mm}$ anterior to the bony nares and this open, slit-like area proceeds anteriorly $120 \mathrm{~mm}$ long. Anterior to this, the two premaxillae get close to each other or contact over the mesorostral canal for about $30 \mathrm{~mm}$, and then they diverge again anteriorly. This arrangement is similar to Kentriodon and Atocetus.

The premaxillae and maxillae are almost vertical near the rostral apex, and they turn horizontally at the base of the rostrum. In the distal one-third of the rostrum the maxillae turn under the premaxillae so that only the premaxillae can be seen in dorsal view.

In the posterior $1 / 4$ of the rostrum the medial part of the premaxillae forms a small, rough area that in extant species corresponds to the attachment site of the nasal plug muscle on either side. This area has the shape of a narrow triangle, which is bordered by the mesorostral gutter medially and by a faint anteromedial premaxillary sulcus laterally. The latter is $40 \mathrm{~mm}$ long, shorter than the same sulcus of Atocetus. There is no posteromedial sulcus. At the level of the premaxillary foramen, the width of the rugose area is $11.5 \mathrm{~mm}$ (including the premaxillary foramen) and its greatest length is $55 \mathrm{~mm}$. The size of the nasal plug muscle attachment site is much smaller in the new species than in Atocetus iquensis, and is similar to Kentriodon pernix.

The posterolateral premaxillary sulcus is a faint groove starting from the premaxillary foramen and progressing posterolaterally. It disappears near the lateral margin of the premaxilla, posterior to the anterior corner of the narial opening. The orientation of the posterolateral sulcus is similar to Kentriodon, Delphinodon dividum, Rudicetus, but differs from Atocetus, where the sulcus reaches more posteriorly, and from Sarmatodelphis, where it turns posteriorly to al- most reach the posterior border of the premaxilla (for an overview see Muizon 1988a: fig. 68).

The posterior part of the premaxilla, which is bordered by the narial opening and the posterolateral and posteromedial sulci, underlie the premaxillary sac in living delphinids (Mead 1975). This area has a flat, smooth surface in M. commenticius as is typical of delphinoids. The distance between the premaxillary foramina and the narial openings is directly related to the size of the premaxillary sac. On the basis of this, Muizon (1988a: 138, fig. 69) aligned the kentriodontids where Liolithax and Atocetus are the most primitive, and Kampholophos serrulus and Delphinodon dividum the most advanced. The premaxillary sac is in large part placed laterally and not anteriorly in the Kentriodontidae, while in the recent Delphinidae it is mostly anterior to the narial openings (Muizon 1988a). In the new species, the presumed premaxillary sac occupied a large area on the premaxilla both anterior and lateral to the narial openings. The distance between the premaxillary foramen and the naris is $45 \mathrm{~mm}$, which is in the range of recent delphinids, placing the new species among the most advanced kentriodontids in this respect.

The posterior termination of the premaxilla is just anterior to the lateral corner of the nasal. Its termination is simple, unlike in A. nasalis, $A$. iquensis, and Pithanodelphis cornutus, where a narrow strip of premaxilla is wedged between the nasal and the maxilla. The posterolateral part of the premaxilla bears a small, slightly elevated area, but this is much smaller than the knob-like lateral projection of Macrokentriodon morani.

Mesethmoid - The narial openings are separated by a moderately thick mesethmoid septum.

Narial opening - The narial openings are elongated, only slightly broadening posteriorly.

Nasal - The description is based on the left nasal bone.

The nasal is thick and robust, but not as large as in Atocetus. Its shape is triangular in the dorsal view, with the lateral corner being rounded off. It is slightly longer than wide. The dorsal surface is almost flat, with the exception of the anteromedial part of the bone, which slopes medially. This slope can be interpreted as a slight internasal fossa, as defined by Muizon (1988b). The anterior edge of the dorsal surface is rugose, and a small anterior process extends from the anterolateral corner of the bone, resulting in a faint anterolateral notch of the nasal. There is no posterolateral process. The lateral margin of the nasal runs parallel to its medial margin in the 
anterior $7 \mathrm{~mm}$, and then it turns medially to reach the posteromedial corner of the bone in a straight line. The two nasal bones probably contacted only at their anteromedial corners, so that they were supposedly separated posteriorly by the frontals. The posterolateral margin of the nasal is surrounded by the maxilla.

The nasal is elevated from the level of the premaxilla and the maxilla by about $8 \mathrm{~mm}$ at its anterior end and progressively less posteriorly.

Frontal - The frontals are not preserved in the vertex area. The supraorbital process is delicately arched in the lateral view. In the area of the preorbital process, the frontal and, especially, the lacrimal form a thick, ventrally pointing process. Because of the sagittal crest of the maxilla, the preorbital process has a somewhat bulbous appearance, comparable to that of Atocetus nasalis, but less pronounced than in A. iquensis.

Lacrimal - The anterior process of the jugal is ankylosed to the lacrimal $6 \mathrm{~mm}$ anterior to the base of the antorbital notch. The lacrimal is wedged between the maxilla and the frontal, if seen from lateral. The anterior edge of the lacrimal, which is not covered by the maxilla, bears rugosities. On the ventral surface of the skull, sutures between the lacrimal and maxilla, as well as the lacrimal and frontal can not be observed on the holotype skull.

Occipital - The exact shape of the occipital shield of Mediocris commenticius is unknown because of the crushing of the holotype skull, but it was likely wider than high, with the exoccipitals projecting ventrolaterally. The exoccipital forms a concave area and meets the squamosal with a prominent, square anterolateral margin. The paroccipital process is prolonged ventrolaterally beyond the level of the inferior border of the alar process of the basioccipital, similarly to Kentriodon. The jugular notch is deep.

The occipital condyles are triangular in shape with a ventromedially pointing apex. They are relatively small for the skull size. Dorsolaterally to the condyle a small depression can be observed on the preserved left side of the occipital shield. The occipital condyles protrude from the occipital shield, but they are not globular. The foramen magnum is roughly circular.

Parietal - The parietals are completely fractured. Shape and size of the temporal fossa is unknown.

Squamosal - The zygomatic process of the squamosal is $70 \mathrm{~mm}$ long as preserved, dorsoventrally shallow, and medially arched. It has a con-

Table 1

Mediocris commenticius n. gen. n. sp. from Kovácsszénája, Hungary. Measurements of the skull, mandibles and tympanic bulla of the holotype, MTM V.93.2 (in mm, $\pm 0.5 \mathrm{~mm}$ ); parentheses denote estimated measurements.

Condylobasal length as preserved (from the first preserved pair of teeth to the posteriormost

Rostrum length from antorbital notches to tip estimated

Rostrum width at antorbital notches

Rostrum width at level of posteriormost dental alveoli

Width of skull at the level of the middle of the orbits

Width of premaxillae across anterior extremity of nares

Greatest width across nares

Greatest length of left naris

Anteroposterior length of left nasal

Greatest mediolateral width of left nasal

Distance between posterior tips of nasals

Length of right zygomatic process from base of sternomastoid muscle fossa to tip

Greatest dorsoventral extension of foramen magnum

Greatest width of foramen magnum

Width across occipital condyles

Greatest extension of occipital condyle

Length of mandibles as preserved

Length of mandibles estimated

Length of mandibular symphysis as preserved

Length of mandibular symphysis estimated

Distance between posteriormost dental alveolus and jugal on the left side

Distance between posteriormost dental alveolus and antorbital notch on the right side

Length of tympanic (between anterior tip and posterior end of outer posterior prominence)

Distance between anterior tip of tympanic and posterior end of inner posterior prominence

Distance between posteroventral tip of outer posterior prominence and tip of conical process 
ical end. On its ventrolateral side, a short, narrow sternomastoid fossa is present posteriorly. The glenoid fossa is wide and shallowly concave. No falciform process is preserved.

Vomer - On the ventral surface of the rostrum the vomer is exposed between the maxillae as a narrow strip of bone in the central part of the rostrum, and the exposed area is $50-60 \mathrm{~mm}$ long.

Pterygoid - The pterygoids are badly crushed. The pterygoid hamuli were probably small.

Tympanic bulla (Table 1, Fig. 5) - The description is based on the right tympanic of the holotype. The sigmoid process and the accessory ossicle are not preserved; the lateral wall anterior to the conus is fractured.

The involucrum is broad in dorsal view and it has a smooth dorsal surface. The dorsal profile of the involucrum has an expressed sinusoid shape, where the anterior part is convex, and the posterior part is depressed and has a concave dorsal contour. In dorsal view, the involucrum has a contour that is concave anteriorly, convex posteriorly. The posterior process is bent posterolaterally and dorsally, and has an elongated pentagonal shape. There are a few broad and shallow grooves on the facet for the connection to the periotic. The posterior process is more elongated posteriorly than the joining posterior process of the periotic. The outer posterior prominence is slightly thicker, and reaches slightly farther posteriorly than the inner posterior prominence. The interprominential notch is deep. The median furrow extends anteriorly to the midlength of the bulla. There is no ventral keel. At its anterior apex the bulla is obtuse. It is unknown whether a lateral furrow was present. The ventral and lateral walls of the tympanic

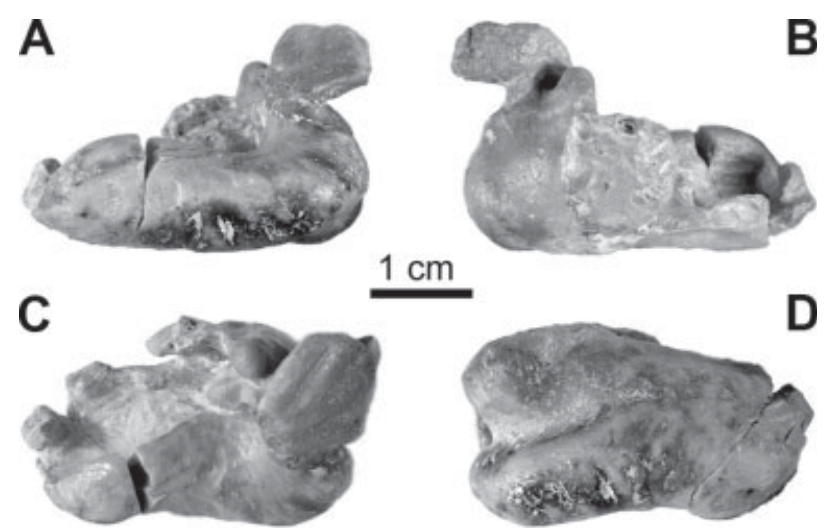

Fig. 5. Mediocris commenticius n. gen. n. sp. from Kovácsszénája, Hungary. MTM V.93.2, right tympanic bulla of the holotype in $\mathbf{A}$ - medial view; $\mathbf{B}$ - lateral view; $\mathbf{C}$ - dorsal view; D - ventral view.
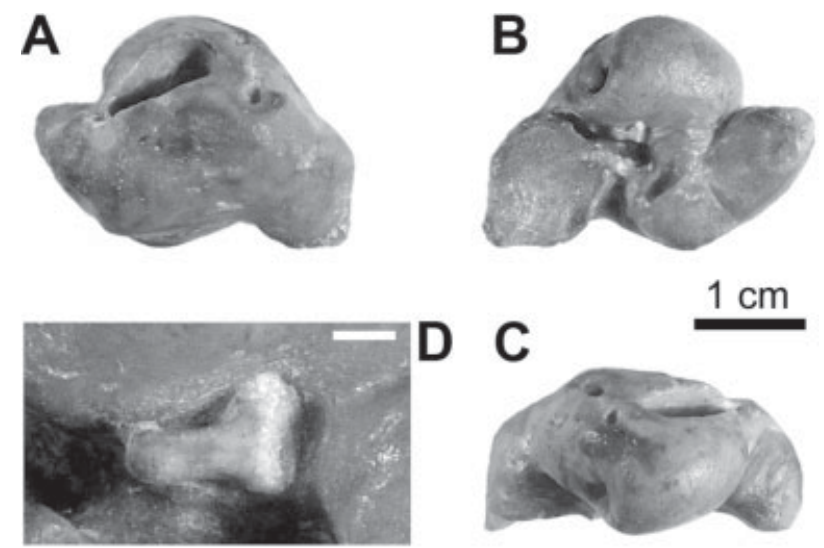

Fig. 6. Mediocris commenticius n. gen. n. sp. from Kovácsszénája, Hungary, MÁFI V.21681. A-C - Left periotic of the holotype in A - dorsal view; B - ventral view; $\mathbf{C}$ - medial view; D - Stapes attached to the left periotic of the holotype.

meet at nearly a right angle. The elliptical foramen was probably open.

The two referred tympanics (MÁFI V.23104 and V.23105) are somewhat larger than the holotype specimen (total lengths as preserved $37.2 \mathrm{~mm}$ and $37.3 \mathrm{~mm}$, respectively vs. $33 \mathrm{~mm}$ ). Both have a deep interprominential notch, a mediolaterally deep involucrum, and a strong sinusoid contour of the involucrum in medial view. MÁFI V.23104 has a few shallow ridges in the medial part of the involucrum. The outer posterior prominence, the lateral wall and its structures, and the posterior process have not been preserved in the referred tympanics.

Stapes - The left stapes of the holotype is preserved, attached to the left periotic. The stapes is elongate, similarly to the same element of Atocetus nasalis, and more elongate than that of Kentriodon pernix and the recent Tursiops. The foot plate is broad, the rim for the annular ligament is relatively narrow. The intercrural aperture is small.

Periotic (Table 2, Fig. 6) - The description is B based on the nearly complete left periotic. It is compact, robust; it has a sinusoid shape, with the anterior process pointing anteromedially and the posterior process pointing posterolaterally.

The anterior process is relatively short and moderately compressed transversely. In medial view it is nearly as obtuse as in modern delphinid periotics. In contrast to these, however, the anterior process has a conical tip in ventral view. The pars cochlearis is large and broadly joined to the body of the periotic. Its mediolateral depth is greater than that of Atocetus, and smaller than that of Delphinodon dividum. The internal auditory meatus is elongated. It has a short slit-like anterior depression, which includes the 
Table 2

Measurements of the periotics of the holotype and referred specimens of Mediocris commenticius $\mathrm{n}$. gen. n. sp. (in mm). All referred periotics are from Danitz-puszta, Hungary. 1. Length of periotic (from tip of anterior process to posterior end of posterior process); 2 . Width of periotic across pars cochlearis and ventrolateral tuberosity; $\mathbf{3}$. Distance between internal auditory meatus and endolymphatic foramen; $\mathbf{4}$. Distance between internal auditory meatus and perilymphatic foramen; $\mathbf{5}$. Distance between endolymphatic and perilymphatic foramina; 6. Anteroposterior diameter of pars cochlearis at base. Mean values were calculated with the exclusion of the right periotic of the holotype.

\begin{tabular}{llllllll}
\hline & $\begin{array}{l}\text { MÁFI V.21681 } \\
\text { (type, left) }\end{array}$ & $\begin{array}{l}\text { MTM V.93.2 } \\
\text { (type, right) }\end{array}$ & MÁFI V.23106 & MÁFI V.23107 & MÁFI V.23108 & MÁFI V.23123 & Mean \\
\hline 1. & 30.0 & appr. 30.0 & 29.3 & 30.2 & 32.6 & 32.9 & 31.0 \\
2. & 21.0 & appr. 21.0 & 21.5 & 21.6 & 23.5 & - & 21.9 \\
3. & 3.2 & 3.1 & 3.4 & 3.9 & 4.6 & - & 3.8 \\
4. & 2.2 & 2.5 & 2.8 & 2.8 & 2.7 & - & 4.6 \\
5. & 3.5 & 3.6 & $4.1 \mathrm{e}$ & 4.3 & 5.1 & - & 20.0 \\
6. & 18.1 & 18.0 & 18.2 & 18.6 & 20.5 & & 19.1
\end{tabular}

internal facial foramen. The fundus of the internal auditory meatus is deep and is inclined at an angle of about $45^{\circ}$ to the body of the periotic. The crista transversa is low. The dorsal surface of the periotic is convex. Lateral to the internal auditory meatus there is a large, flat area that slopes laterally. This broad area gives the periotic a rather massive appearance. The endolymphatic foramen lies slightly medial to the plane defined by the base of the pars cochlearis. The perilymphatic foramen is a small aperture opening dorsally in the virtual elongation of the long axis of the internal auditory meatus.

The articular facet of the posterior process has the shape of an elongated pentagon, it is shallowly concave and almost completely smooth. The same surface of the right periotic bears three shallow grooves and fine ridges, which interdigitate with the grooves and ridges of the posterior process of the right tympanic bulla. The posterior process is not considerably inflected ventrally: in lateral view the articular facet of the posterior process lies in the same horizontal plane as the ventral surface of the

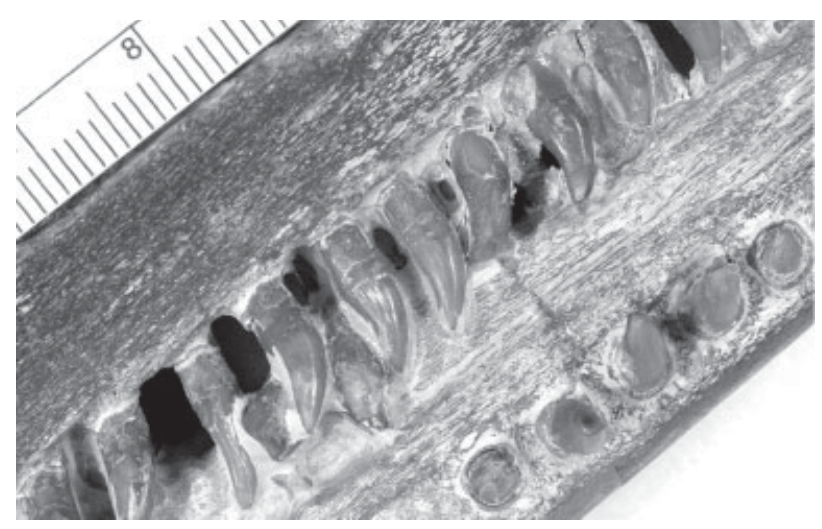

Fig. 7. Mediocris commenticius n. gen. n. sp. from Kovácsszénája, Hungary. MTM V.93.2, in situ maxillary teeth in lateral view, and mandibular teeth in top view. anterior process. The fossa for the head of the malleus is shallow and elliptical. The ventrolateral tuberosity is prominent. The hiatus epitympanicus is moderately deep and narrow.

Four periotics from Danitz-puszta are referred to the new genus and new species (Table 2). All have the same general morphology as the holotype. There are differences in the shape of the fundus of the internal auditory meatus: in MÁFI V.23106 and V.23108 it is elliptical, and the internal facial foramen has a separate opening anterolaterally from the fundus, contrary to the holotype periotics. The V.23108 periotic has a widened plateau projecting posteromedially from the endolymphatic foramen, which makes the periotic look extremely robust.

Mandible - The apex of the mandibles and the posterior part of the right ramus are missing, the same part of the left ramus is badly shattered. The latter is appressed to the palatal surface of the skull and thus, the morphology of the medial and dorsal surfaces of the mandible as well as the posterior termination of the mandibular tooth row is unknown (Figs 3, 4).

The profile of the lower jaw in ventral view is a narrow Y shape. The symphysis takes up approximately $37 \%$ of the estimated total length of the mandibles. The two rami were ankylosed in the symphyseal part. The symphyseal part of each dentary bears alveoli for ca. 21 teeth. In lateral view, the mandible is delicately upturned anteriorly, and in the posterior symphyseal region it has a deeper, keeled profile. The toothbearing portion of each dentary is broad dorsally, narrow ventrally. Posterior to the alveoli, the dentary expands dorsally and ventrally. In this part, the bone is thin. The coronoid process is turned slightly laterally. Each mandibular ramus bears 3-4 mental foramina spaced along its anterior lateral surface. 
Teeth (Fig. 7) - Most preserved teeth remained in situ, although some of the crowns are broken off, and a few were distorted from their alveoli. Teeth of the right mandibular ramus and the left maxilla more or less preserved their original orientations.

Although the tip of the lower jaw is not preserved, probably no more than one pair of teeth of the mandibles is missing. The orientation of the first preserved pair of mandibular teeth is obliquely forward-pointing. The termination of the upper tooth rows is more problematic because the maxillae and premaxillae were badly preserved anteriorly. It is possible that all anterior teeth are preserved. As far as the rostrum is preserved anteriorly, all teeth sit in the maxilla, none in the premaxilla. Alveolar counts as preserved are 38 for the upper left row, 34 for the upper right row, 27 for the lower left row, and 34 for the lower right row. The estimated number of teeth is 38-39 for each row.

The alveoli are deep, circular and evenly spaced: there are roughly two teeth per centimeter. Except for the smaller posteriormost three, all alveoli are about $4 \mathrm{~mm}$ in diameter and they are directed dorsally.

The teeth have neither carinae nor accessory cusps and are single-rooted. The enamel is smooth, having only fine clefts. The largest teeth are in the middle and in the anterior part of the tooth row, where they measure $16.0-16.1 \mathrm{~mm}$ in length, whereas the teeth of the posterior region are progressively smaller. Diameter of the crowns at base averages $3.7 \mathrm{~mm}$, crowns comprise about one-third of the total length. The tooth crowns are slightly compressed antero-posteriorly. Teeth in the anterior and middle part of the rows are slender with slightly curved crowns whereas the posterior teeth have more intensively recurved apices. The roots are straight, tapering gradually toward the apex (posterior teeth) or curved and slightly enlarged below the crown (central and anterior teeth). The roots are covered by a layer of cementum.

Vertebrae - All seven cervical, the first six and two additional thoracic, two lumbar and 17 caudal vertebrae are preserved. The assignment of the lumbar and caudal vertebrae to their correct positions in the column is not possible.

An unknown number of thoracic, lumbar and caudal vertebrae are missing. Using the regression equation of Buchholtz \& Schur (2004: 6B), a total vertebral count of approximately 42 can be estimated for the new species (average centrum length/centrum height of the two preserved lumbar vertebrae is 1.275), although this method was developed for the Delphinidae.

Cervical (Table 3, Figs 8, 9) - The atlas and the axis are fragmentary, the other cervical vertebrae are crushed against each other.

All cervicals are free. The anterior articular facet of the atlas is slightly concave anteriorly and kidney-shaped, whereas the posterior articular facet is subovoidal and convex. The vertebral foramen was wide. The transverse process of the atlas is moderately long and projects posterolaterally. The anterior articular facet of the axis is shallowly concave and kidney-shaped. The vertebral foramen is narrow in comparison to the atlas.

The postaxial cervicals are all very thin anteroposteriorly $(4.5-5.8 \mathrm{~mm})$. The sixth cervical is best preserved. Its centrum is slightly thicker than that of the preceeding vertebra. In posterior view, the centrum of the $6^{\text {th }}$ cervical is roughly circular. The neural arch is slender and relatively low. The ventral transverse process is directed ventrolaterally. It is compressed dorsoventrally and thickened anteroposteriorly, especially toward its preserved distal end. The dorsal transverse process starts on the neural arch and it is directed laterally.

Thoracic (Table 3, Fig. 9) - The $1^{\text {st }}-7^{\text {th }}$ thoracic vertebrae are crushed against one another

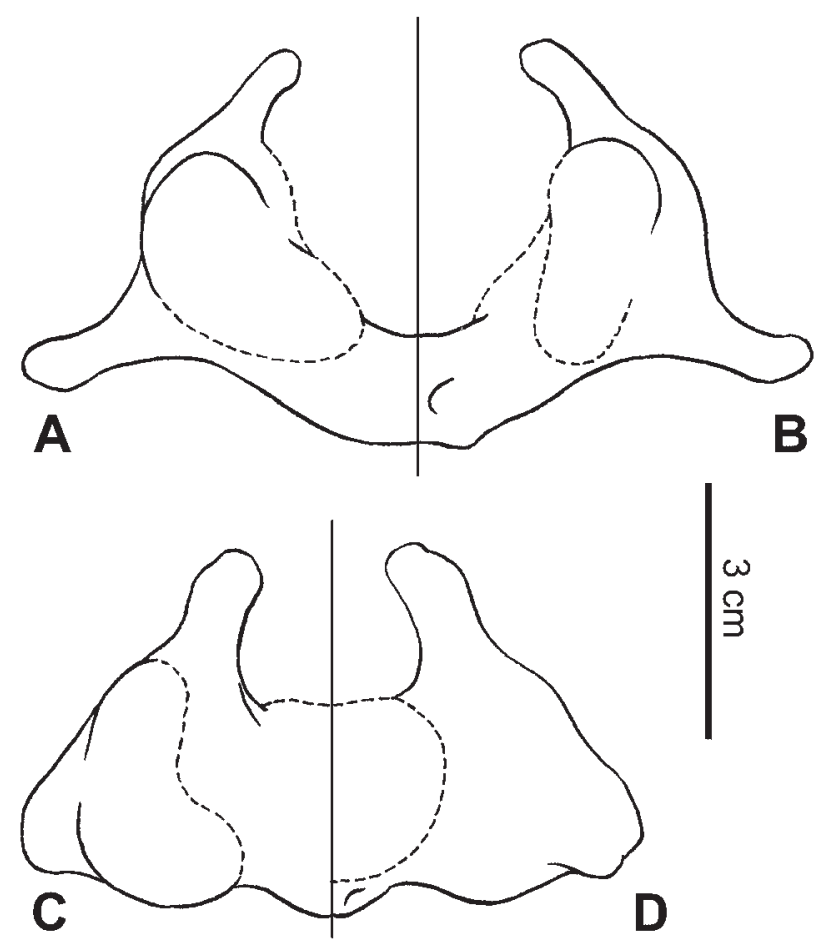

Fig. 8. Mediocris commenticius n. gen. n. sp. from Kovácsszénája, Hungary. MTM V.93.2, atlas and axis of the holotype, partial restoration. A, B - atlas in anterior and posterior view; $\mathbf{C}, \mathbf{D}-$ axis in anterior and posterior view. 


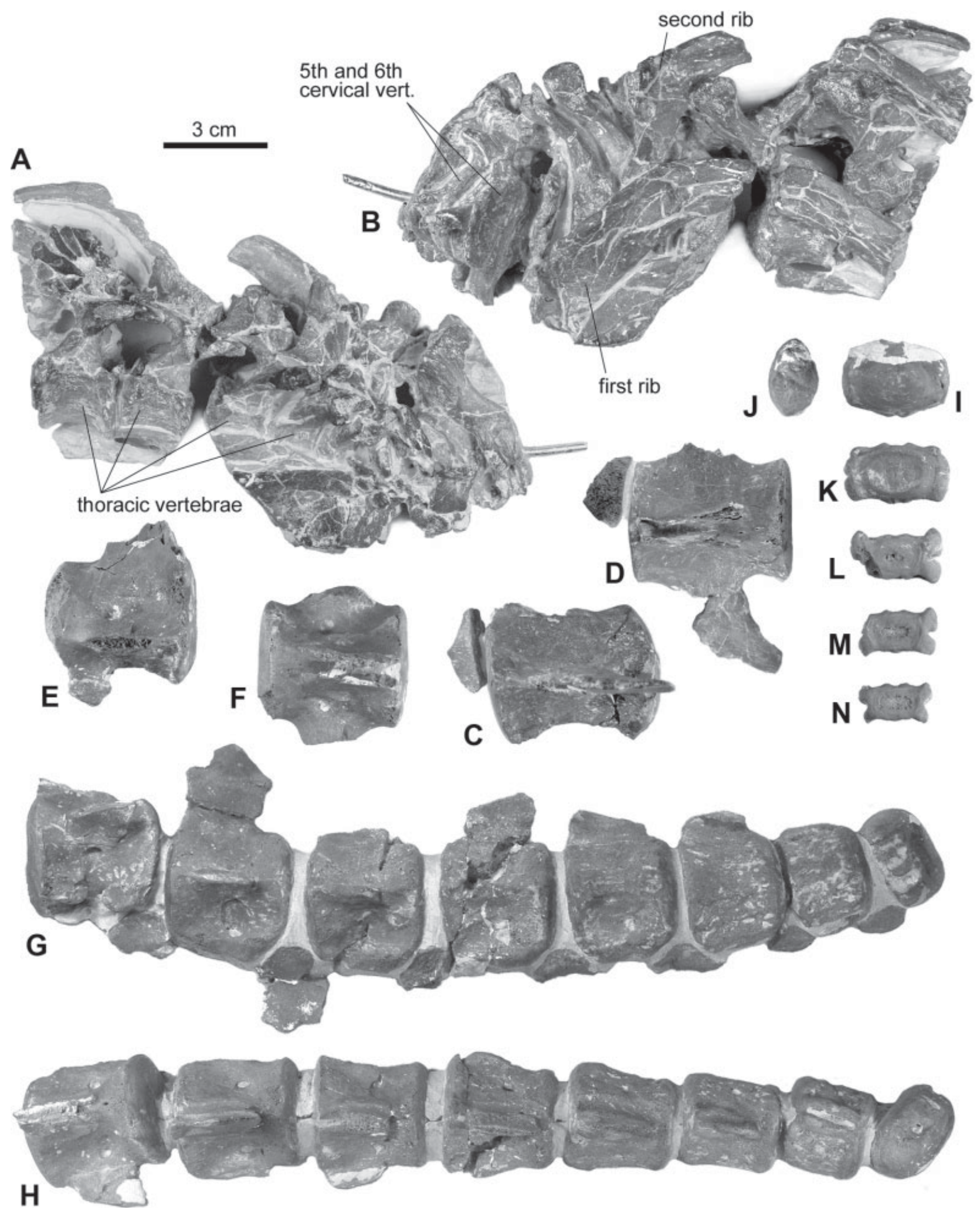

Fig. 9. Mediocris commenticius n. gen. n. sp. from Kovácsszénája, Hungary. MTM V.93.2, vertebrae and ribs of the holotype. $\mathbf{A}, \mathbf{B}-$ Postaxial cervical vertebrae, thoracic vertebrae $1^{\text {st }}$ through $7^{\text {th }}$, and rib fragments in a block, $\mathbf{A}$, from the right side; B, from the left side; $\mathbf{C}, \mathbf{D}$ - First preserved caudal vertebra $\mathbf{C}$, from left lateral and $\mathbf{D}$, from dorsal; E, $\mathbf{F}-$ Second preserved caudal vertebra $\mathbf{E}$, from right lateral; $\mathbf{F}$, from dorsal; $\mathbf{G}, \mathbf{H}-$ The $4^{\text {th }}$ through $11^{\text {th }}$ preserved caudal vertebrae in a block $\mathbf{G}$, from left lateral; $\mathbf{H}$, from dorsal; $\mathbf{I}, \mathbf{J}-$ The $12^{\text {th }}$ preserved caudal vertebra $\mathbf{I}$, from anterior; $\mathbf{J}$, from lateral; K-N - Terminal (fluke) caudal vertebrae.

and in part covered by other fragments. The $8^{\text {th }}$ thoracic is missing, the next preserved ones (presumably the $9^{\text {th }}$ and the $\left.10^{\text {th }}\right)$ are shattered.
Vertebral body lengths increase posteriorly in the series. There is no ventral keel on any of the preserved thoracic vertebrae. The vertebral epi- 


\section{Table 3}

Mediocris commenticius n. gen. n. sp. from Kovácsszénája, Hungary. Measurements of the preserved vertebrae of the holotype, except the terminal caudals (in $\mathrm{mm}, \pm 0.5 \mathrm{~mm}$ ). Numbers in the posterior thoracic (Th. 9-10), lumbar and caudal series indicate sequence of preservation and not anatomical positions. Th. 9 - MÁFI V.21682/2; Th. 10 - MÁFI V.21682/1. All others - MTM V.93.2. Ce - cervical, Th - thoracic, L - lumbar, Ca - caudal vertebrae.

1. length of vertebral body; 2. depth of anterior epiphysis; $\mathbf{3}$. depth of posterior epiphysis; $\mathbf{4}$. width of anterior epiphysis; $\mathbf{5}$. width of posterior epiphysis; $\mathbf{6}$. width of transverse process at base; RCL: relative centrum length calculated with the method of Buchholtz (2001); + : original value definitely larger; e: estimation.

\begin{tabular}{|c|c|c|c|c|c|c|c|c|}
\hline & & 1. & 2. & 3. & 4. & 5. & 6. & RCL \\
\hline \multirow[t]{7}{*}{ Ce. } & 1. & - & - & - & - & - & - & \\
\hline & 2. & 19.0 & - & - & - & - & - & \\
\hline & 3. & $5.5 \mathrm{e}$ & - & - & - & - & - & \\
\hline & 4. & $4.5 \mathrm{e}$ & - & - & - & - & - & \\
\hline & 5. & $5.0 \mathrm{e}$ & - & - & - & - & - & \\
\hline & 6. & $6.0 \mathrm{e}$ & - & 27.5 & - & 27.0 & - & 0.2 \\
\hline & 7. & $6.0 \mathrm{e}$ & - & - & - & - & - & \\
\hline \multirow[t]{10}{*}{ Th. } & 1. & $11.5 \mathrm{e}$ & - & - & - & - & - & \\
\hline & 2. & - & - & - & - & - & - & \\
\hline & 3. & $14.5 \mathrm{e}$ & - & - & - & - & - & \\
\hline & 4. & $18.0 \mathrm{e}$ & - & - & - & - & 11.5 & \\
\hline & 5. & $20.0+$ & 17.5 & - & 20.0 & - & $11.5 \mathrm{e}$ & \\
\hline & 6. & 24.5 & - & 20.5 & - & 24.5 & - & 1.1 \\
\hline & 7. & $25.0 \mathrm{e}$ & - & - & - & - & - & \\
\hline & 8. & - & - & - & - & - & - & \\
\hline & 9. & 32.0 & $25.0 \mathrm{e}$ & - & $25.0 \mathrm{e}$ & - & - & 1.3 \\
\hline & 10. & 33.5 & $23.5 \mathrm{e}$ & - & $26.5 \mathrm{e}$ & - & - & 1.3 \\
\hline \multirow[t]{2}{*}{ L. } & 1. & $43.5+$ & 33.5 & - & 34.0 & - & 22.0 & \\
\hline & 2. & $42.0+$ & 33.5 & - & 33.0 & - & - & \\
\hline \multirow[t]{10}{*}{ Ca. } & 1. & 43.0 & 32.5 & 34.0 & 33.0 & 34.0 & $20.5 \mathrm{e}$ & 1.3 \\
\hline & 2. & 41.0 & - & - & 35.0 & - & - & \\
\hline & 3. & 39.5 & 33.0 & - & 34.0 & - & 22.0 & 1.2 \\
\hline & 4. & 38.0 & 33.0 & - & 34.0 & 33.5 & $19.0 \mathrm{e}$ & 1.1 \\
\hline & 5. & $37.0 \mathrm{e}$ & 33.5 & - & 34.0 & 32.5 & $21.0 \mathrm{e}$ & 1.1 \\
\hline & 6. & $34.5 \mathrm{e}$ & - & - & 34.5 & 31.5 & 18.5 & \\
\hline & 7. & $34.0 \mathrm{e}$ & $36.0 \mathrm{e}$ & $33.0 \mathrm{e}$ & 333.5 & 29.5 & $18.5 \mathrm{e}$ & 1.0 \\
\hline & 8. & $32.0 \mathrm{e}$ & $32.0 \mathrm{e}$ & $30.0 \mathrm{e}$ & 30.5 & 27.0 & - & 1.0 \\
\hline & 9. & $29.5 \mathrm{e}$ & $31.5 \mathrm{e}$ & 31.0 & 27.0 & 26.5 & - & 1.0 \\
\hline & 10. & $25.5 \mathrm{e}$ & $29.0 \mathrm{e}$ & 27.5 & 26.0 & 27.0 & - & 0.9 \\
\hline
\end{tabular}

physes have either a triangular or a semicircular outline. In lateral view the ventral aspect of the centra is concave, more so in the $5^{\text {th }}-6^{\text {th }}$ than with the following ones. Parapophyses for articulation with the costal heads are present on the centra of the $4^{\text {th }}$ and $6^{\text {th }}$ dorsal vertebrae, unknown with the other ones. The transverse processes are set high on the neural arches. The diapophyses are directed anterolaterally and flattened dorsoventrally. Their distal ends turn in lateral direction and thicken anteroposteriorly near the articular facets. The neural canal is higher than wide. The articular facets of the preand postzygapophyses are longer than wide and elevated obliquely in the lateral direction.

Lumbar (Table 3) - Two incomplete lumbar vertebrae are lacking their processes and portions of their centra. The anteroposterior extension of the transverse process at base takes up $50 \%$ of the estimated central length. The centra of the preserved lumbars are longer than wide or high, and they are ventrally keeled. The anterior epiphyses are nearly circular in anterior view.

Caudal (Tables 3, 4, Fig. 9) - The first, second and third preserved caudals were probably not the first, second and third in life, nevertheless they originate from the anterior caudal region. The next eight consecutive vertebrae with fragments of their chevron bones are preserved together in a block. Six separately preserved terminal caudal vertebrae constitute the end of the series. A few more might have been lost from the terminal (fluke) region.

The centrum of the first preserved caudal is longer than wide or high (Fig. 9 C, D). In lateral view the anterior and posterior faces of the centrum are slightly leaning forward. The neural canal is narrow, the neural arch is shifted to the anterior part of the centrum. The transverse process connects to the vertebral body with a broad base. It is shifted slightly anteriorly on the cen- 


\section{Table 4}

Mediocris commenticius n. gen. n. sp. from Kovácsszénája, Hungary. Measurements of the preserved terminal caudal vertebrae of the holotype, MTM V.93.2 (in mm, $\pm 0.5 \mathrm{~mm}$ ). Numbers indicate presumed anatomical sequence but not positions in the vertebral column. L: length of vertebral body; $\mathrm{H}$ : depth of vertebral body; W: width of vertebral body.

\begin{tabular}{lrlr}
\hline & \multicolumn{1}{l}{ L } & H & W \\
\hline Ca. 11. & 19.0 & 27.5 & 29.0 \\
Ca. 12. & 12.0 & 20.5 & 29.5 \\
Ca. 13. & 9.5 & 16.5 & 30.0 \\
Ca. 14. & 9.0 & - & - \\
Ca. 15. & 8.5 & 12.5 & 27.0 \\
Ca. 16. & 8.0 & 11.5 & appr. 23.0 \\
Ca. 17. & 7.0 & 10.0 & 21.0
\end{tabular}

trum. Its posterior margin is concave so that the transverse process, albeit largely incomplete, must have had a large distal expansion posteriorly, similarly to the triangular lamina of the lumbar vertebrae observed with most Delphinida (Muizon 1985, 1988b). However, the latter is always on the anterior margin of the transverse process.

The next seven caudal vertebrae are more uniform (Fig. 9: E-H). The bases of their transverse processes are perforated by a large vertical hole both dorsally and ventrally. A well-marked groove for vertebral arteries leads dorsally and

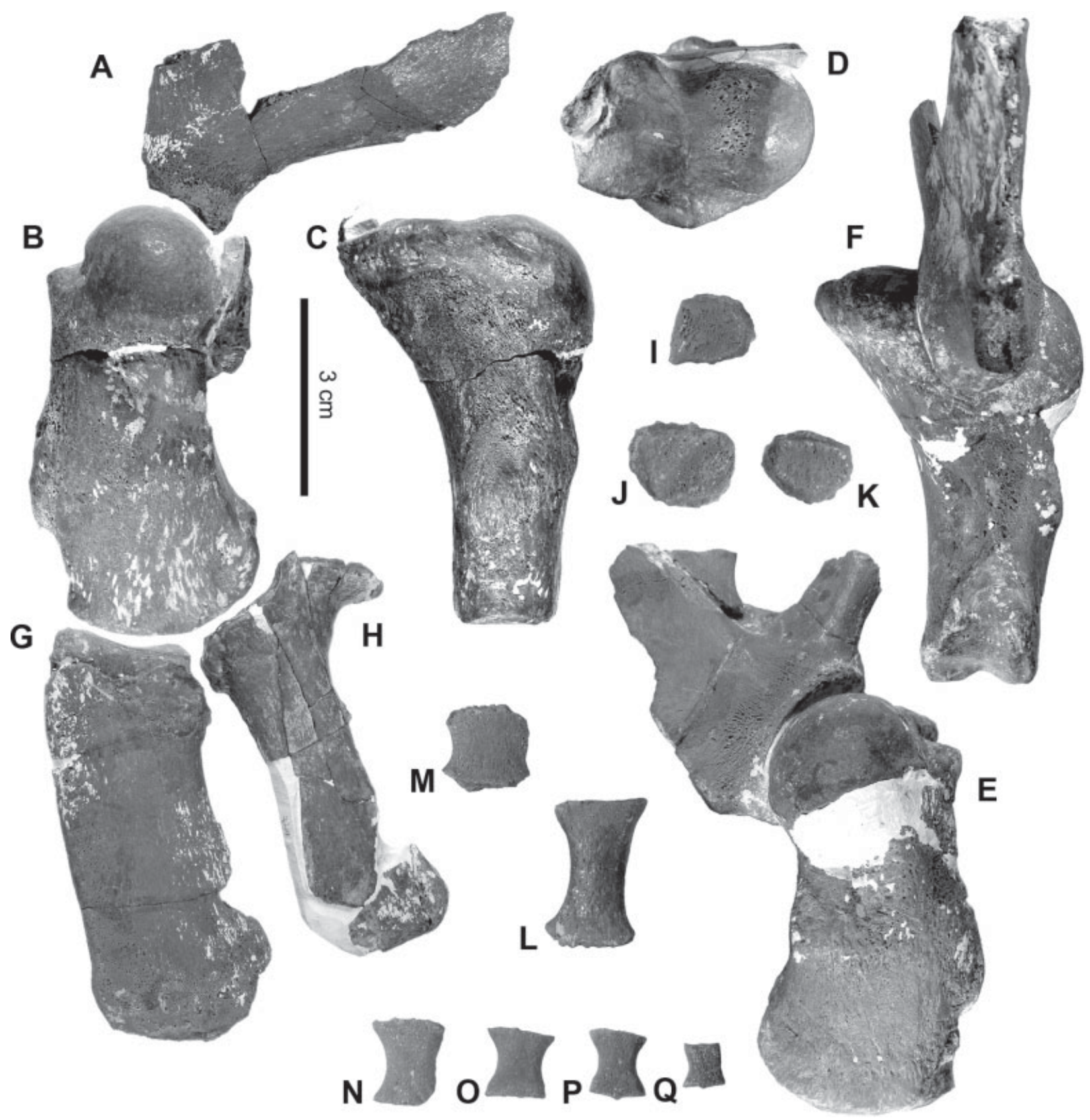

Fig. 10. Mediocris commenticius n. gen. n. sp. from Kovácsszénája, Hungary. MTM V.93.2, elements of the shoulder, arm, carpus and manus of the holotype. A - Left scapular fragment in lateral view; $\mathbf{B}-\mathbf{D}$ - Left humerus $\mathbf{B}$, in lateral view; $\mathbf{C}$, in anterior view; D, in dorsal view; E, F - Right humerus and attached scapular fragment $\mathbf{E}$, in lateral view; $\mathbf{F}$, in posterior view; $\mathbf{G}-$ Right radius in medial view; $\mathbf{H}$ - Left ulna in lateral view; $\mathbf{I}-\mathbf{K}$ - Carpals, I, scaphoid; $\mathbf{L}-\mathbf{Q}$ - Metacarpals and phalanges. 
posteriorly from the foramen on both sides of each of these vertebrae. The neural spine of caudal 5 is moderately high and slightly inclined forward. The neural spine has an oblique, anteriorly sloping rim on both lateral sides. The neural arches are set anteriorly on the centra. The neural canals are progressively narrower and the transverse processes smaller posteriorly; the $8^{\text {th }}$ preserved caudal vertebra has only a faint eminence on the lateral side of its centrum. The anterior and posterior faces of the vertebral bodies are more or less vertical. The epiphyses of caudals 1-4 are nearly circular. The centra of the anterior caudals are cuboid, those of the posterior ones are deeper than long or wide. Caudals 810 are compressed laterally. Posterior facets for the articulation with the chevron bones are very prominent on caudals 3 and 4. On the following ones, anterior and posterior ventral keels meet, enclosing a ventral foramen on each side. Seven chevron bones are preserved, those that are positioned between the caudals $4-11$.

The $12^{\text {th }}$ preserved caudal is more expanded transversely than the previous ones, and has a rounded anterior facet (Fig. 9: I, J). This element was the point of caudal flexion at the junction of the peduncle and the fluke. All vertebrae posterior to this are expanded transversely, compressed anteroposteriorly and dorsoventrally, as is usual for the terminal caudal vertebrae.

Scapula (Fig. 10: A, E, F) - Fragments of both scapulae are preserved. The glenoid fossa is moderately concave and elliptical in shape (length: $24.4 \mathrm{~mm}$; width: $17.1 \mathrm{~mm}$ ). The posterior margin of the blade has a concave profile at the base, and becomes straight dorsal and posterior to this concavity. The gracile coracoid process is directed anteriorly. The supraspinous fossa is narrow at the insertion of the acromion.

Humerus (Table 5, Fig. 10) - Both humeral heads are partially covered by scapular fragments. The description is a composite of both humeri.

The humerus is elongated and robust with well-marked muscle attachment sites. In frontal view it is relatively thick, narrowing distally. In lateral view the shaft does not significantly broaden distally, i.e. the anterior and posterior margins run nearly parallel. The anterior margin is convex, the posterior margin is concave, so that the bone has an arched appearance. The head is small, which means that the dorsoventral depth of the humeral head takes up about onethird of the total length of the humerus. The greater tuberosity is well-defined. The lesser tuberosity forms a large, posteriorly pointing trian-
Table 5

Mediocris commenticius n. gen. n. sp. from Kovácsszénája, Hungary. Measurements of the humerus of the holotype and referred specimens (in $\mathrm{mm}, \pm 0.5 \mathrm{~mm}$ ); e: estimation. Mean values were calculated with the exclusion of the right holotype humerus. All referred humeri are from Danitz-puszta, Hungary. LC140: from the private collection of Zoltán Evanics (Mindszent, Hungary); MR: from the private collection of Roland Molnár (Pécs, Hungary); OZ: from the private collection of Zoltán Orbán (Bonyhád, Hungary). 1. Total length; 2. Least anteroposterior extension of shaft; $\mathbf{3}$. Least mediolateral extension of shaft; $\mathbf{4}$. Mediolateral extension of proximal epiphysis; 5. Anteroposterior extension of proximal epiphysis; 6. Anteroposterior extension of distal epiphysis; 7. Mediolateral extension of distal epiphysis.

\begin{tabular}{llllllll}
\hline & 1. & 2. & 3. & 4. & 5. & 6. & 7. \\
\hline holotype, left & 59.5 & 22.5 & 18.5 & 37.0 & 25.5 & 28.5 & 16.0 \\
holotype, right & 59.5 & 23.0 & 20.5 & 39.0 & 26.5 & 29.0 & 16.5 \\
MTM V.60.707 & 70.0 & 24.0 & 20.5 & 41.0 & 27.0 & 31.0 & 19.0 \\
LC140-4598 & 70.5 & 22.5 & 23.5 & 40.5 & 28.0 & 31.5 & 17.5 \\
LC140-4602 & 61.5 & 23.0 & 20.0 & 37.5 & 27.0 & 27.5 & 16.5 \\
LC140-4652 & 65.0 & 23.0 & 21.5 & 40.5 & 27.0 & 29.5 & 17.0 \\
M274R & 66.0 & 23.5 & 22.5 & 40.5 & 28.5 & 31.5 & 18.0 \\
OZ-22 & 68.0 & 23.0 & 22.5 & 40.5 & 24.5 & 31.5 & 16.0 \\
OZ-45 & 61.0 & 22.5 & 22.5 & 37.5 & 25.5 & 28.0 & 17.0 \\
OZ-75 & 62.0 & 21.5 & 22.5 & 36.5 & 24.5 & 27.5 & 16.5 \\
min. & 59.5 & 21.5 & 18.5 & 36.5 & 24.5 & 27.5 & 16.0 \\
max. & 70.5 & 24.0 & 23.5 & 41.0 & 28.5 & 31.5 & 19.0 \\
mean & 64.8 & 22.3 & 21.6 & 39.1 & 26.4 & 29.6 & 17.1
\end{tabular}

gular plateau. The posterior portion of the lesser tuberosity is not elevated. The posterior tuberosity is set high on the shaft: its center lies in the level of the distal margin of the infraspinous fossa. The infraspinous fossa is a shallow depression on the longitudinal axis of the humeral shaft. The deltoid tuberosity forms a strong eminence on the anterior margin of the humerus. It is positioned centrodistally, being well-separated from the distal epiphysis. The facet for the olecranon process of the ulna is large.

Radius and Ulna (Table 6, Fig. 10) - The right radius of MTM V.93.2 is nearly complete, the left one lacks the entire posterior margin and the

Table 6

Mediocris commenticius n. gen. n. sp. from Kovácsszénája, Hungary. Measurements of radius and ulna of the holotype, MTM V.93.2 (in mm, $\pm 0.5 \mathrm{~mm}$ ).

\begin{tabular}{lrr}
\hline & radius & ulna \\
\hline Total length & 65.5 & 58.5 \\
Least anteroposterior length & 22.5 & 15.0 \\
Least mediolateral width & 9.0 & 8.5 \\
$\begin{array}{l}\text { Greatest anteroposterior extension } \\
\text { of proximal epiphysis }\end{array}$ & 20.5 & 18.5 \\
$\begin{array}{l}\text { Greatest mediolateral extension of } \\
\text { proximal epiphysis }\end{array}$ & 14.0 & 14.5 \\
$\begin{array}{l}\text { Greatest anteroposterior extension } \\
\text { of distal epiphysis }\end{array}$ & appr. & appr. \\
Greatest mediolateral extension of & 29.0 & 23.0 \\
& 10.5 & 9.0
\end{tabular}

distal epiphysis 
Table 7

Mediocris commenticius n. gen. n. sp. from Kovácsszénája, Hungary. Measurements of the presumed metacarpal (9) and phalanges (10-14) of the holotype, MTM V.93.2 (in mm). The numbers refer to L-Q of Fig. 10, and do not imply anatomical positions or identifications.

\begin{tabular}{|c|c|c|c|c|c|c|}
\hline & 9 & 10 & 11 & 12 & 13 & 14 \\
\hline Total proximodistal length & 22.0 & 13.3 & 13.3 & 10.7 & 10.6 & 6.9 \\
\hline Greatest (medio-lateral) extens. & 8.4 & 5.7 & 5.6 & 4.3 & 4.0 & 2.8 \\
\hline Greatest antero-posterior extens. & 13.9 & 13.6 & 11.3 & 10.3 & 8.8 & 6.5 \\
\hline Least antero-posterior extension & 8.4 & 11.4 & 7.6 & 6.8 & 5.8 & 5.0 \\
\hline
\end{tabular}

distal epiphysis. Of the right ulna only the proximal epiphysis is preserved, the left ulna is incomplete.

The lower arm of Mediocris commenticius is of the same length as the humerus. The radius and the ulna are flattened mediolaterally, they are proximally moderately thick and become progressively thinner distally. The radius is delicately arched with a leading edge that is convex on its proximal part and straight distally. The posterior margin is slightly excavated so that there is a gap between the radius and the ulna for the antebrachial muscles.

The radius and the ulna articulate at their proximal ends; the articular facet is large, nearly circular in the radius and small, semicircular in the ulna. The ulna has a slightly concave anterior margin and a straight posterior margin. The preserved part of the distal epiphysis has a straight contour. There is a faint depression of a blood vessel in the proximal part of the medial surface of the ulna leading from the anterior margin towards the olecranon process. The olecranon process is well-developed, flag-like.

Carpus and Manus - 11 carpals, 20 metacarpals and phalanges (or their fragments) are preserved. The exact arrangement and the identification of the elements are unclear. Of the carpals, the scaphoid could be identified: it is small and has a straight anterior margin (Fig. 10: I). Its cross-section is triangular, being thick posteriorly, where it faces the lunar. The fragments of three other carpals preserved in a small piece of matrix show that these bones were widely spaced. The space between the carpals was probably filled with cartilaginous tissue, as concluded from the rough, pock-marked articular surfaces of all preserved carpals. The same holds for the proximal and distal epiphyses of all preserved metacarpals and phalanges. The shape and size of the metacarpals and phalanges varies considerably: some (presumably the metacarpals and the proximal phalanges) are thick, narrow and elongated, others (some of the more distal phalanges) are thin, squared and short (Fig. 10: L-
Q). Measurements of the best preserved metacarpals and phalanges are given in Table 7.

Ribs - The proximal parts of two ribs, apparently the first and second left ones, belong to the holotype. The first rib has a large capitulum, a flat tuberculum and a short collum (Fig. 9: B). The body is wide and compressed anteroposteriorly. It is strongly curved at its proximal end, but not as strongly as the same rib of Kentriodon pernix and Atocetus iquensis. The second rib has a small capitulum, a well-marked tuberculum and a narrow neck.

\section{Discussion}

\section{Paleobiology}

Ontogenetic age and body size - It is generally accepted that the state of fusion of vertebral and limb bone epiphyses to the shafts is an indicator for physical maturity (e.g. Perrin 1975). In the type specimen of $M$. commenticius all preserved vertebrae, including those from the central part of the vertebral column, possess epiphyses completely fused to the centra, indicating that the specimen had reached physical maturity. This is further evidenced by the fused proximal and distal epiphyses of the arm bones.

The larger size of most periotics and humeri referred to $M$. commenticius (Tables 2, 5) indicates that the holotype specimen was a small individual of the species.

Swimming performance - The cervical vertebrae of $M$. commenticius are unfused but foreshortened, indicative of a short neck. The relative centrum length (RCL) of the $6^{\text {th }}$ cervical vertebra of the holotype is somewhat larger (0.2) than those of modern delphinids, and comparable to the recent Monodon (definitions and comparative data from Buchholtz 2001). Relative centrum lengths calculated for the preserved torso vertebrae are listed in Table 3. The posterior thoracic and the anteriormost caudal vertebra have the largest values; they are considerably 
longer than high or wide (RCL: 1.3). The following caudal vertebrae have progressively smaller relative centrum lengths with RCL values smaller than 1.0 at the junction between the peduncle and the fluke.

The short posterior torso vertebrae and the long anterior torso vertebrae are typical of the Pattern 2 cetaceans of Buchholtz (2001). These are characterized by a long and stable peduncle, whereas the posterior thoracic and lumbar vertebrae retain long central lengths, giving this area of the vertebral column flexibility (Buchholtz 2001). According to Buchholtz (2001), cetaceans of Pattern 2 include the present-day $\mathrm{Zi}$ phiidae, Monodontidae, all river dolphins, and fossils such as the Early Miocene Eurhinodelphis bossi Kellogg, 1925 and the Middle Miocene $\mathrm{Ha}$ drodelphis calvertense.

The above mentioned examples and the newly described species suggest that Pattern 2 may be a common vertebral structure in Miocene to Recent non-physeterid Odontoceti (see also Buchholtz \& Schur 2004). The phylogenetically younger Albireonidae, Phocoenidae and Delphinidae belong to the Pattern 3 of Buchholtz (2001). In addition, the Middle Miocene kentriodontid Atocetus iquensis is probably also a Pattern 3 odontocete, with only the thoracic and the first lumbar vertebrae of the torso having relative centrum lengths slightly greater than 1.0 (values calculated from the measurements of Muizon 1988a).

The relatively small humeral head of M. commenticius probably indicates that the species was not adapted to fast swimming. It is well-known that all pelagic, fast-moving species of the Delphinidae and Phocoenidae have extremely enlarged humeral heads, whereas odontocetes with more maneuverability of the flippers have elongated humeri with relatively smaller heads (e.g. Benke 1993).

\section{Systematic and phylogenetic considerations}

Mediocris commenticius is a delphinoid because it has the characteristic development of the anterior process of the periotic and the ventral transverse process of the atlas typical of the Delphinoidea, as discussed by Muizon (1988a). The species is grouped in the Kentriodontidae because it lacks synapomorphies of other families of the Delphinoidea as defined by Barnes (1984), Muizon (1988b, 1993), Fordyce \& Muizon (2001). Specifically, it differs from the Phocoenidae and the Albireonidae in the lack of premax- illary eminences; from the Delphinidae in the lack of anteroposteriorly shortened nasals and a strongly developed mesethmoid; from the Monodontidae in that it does not have a medial maxillary-premaxillary suture that extends posteriorly along the lateral margin of the narial openings; and from the Odobenocetopsidae in the lack of the extreme modifications of the skull observed with this family.

The taxonomy and systematics of the family Kentriodontidae Slijper, 1936, as defined by Barnes (1978), has never been settled. Although several attempts have been made to clarify the phylogenetic relationships among established subfamilies and genera (e.g. Barnes 1978, 1985; Muizon 1988a, 1988b; Dawson 1996a), the monophyly of the subfamilies could not be demonstrated synapomorphically (Muizon 1988a, 1988b; Ichishima et al. 1994).

The least debated is the content of the Kentriodontinae Slijper, 1936, as discussed by Dawson (1996b). This subfamily, as proposed by Muizon (1988b), unites species with a low and tabular vertex, anteroposteriorly short nasals with an anterolateral notch and a concave posterior margin. However, two more recently described genera that were placed in the Kentriodontinae by their authors (Dawson 1996b; Bianucci 2001) weakened the significance of the anterior notch and the posterior concavity of the nasals, as each of these new genera failed to exhibit one of these characters (Bianucci 2001). Mediocris commenticius is not a kentriodontine because its vertex is not tabular. Neither can it be assigned to the Lophocetinae Barnes, 1978, because the cranial vertex and the nasals are not constricted from the sides as in the species of this subfamily as defined by Barnes (1978), Muizon (1988b), and Fordyce \& Muizon (2001).

The Pithanodelphininae Barnes, 1985 includes species with slightly asymmetrical skull, elevated vertex, large or inflated nasals, and maxillae which get close to or reach the midline of the skull behind the nasals. In this concept, Pithanodelphis, Atocetus, Sarmatodelphis, and Leptodelphis are included in the Pithanodelphininae (Barnes 1985; Muizon 1988b; Fordyce \& Muizon 2001; Kazár \& Grigorescu in press). The presence of an internasal fossa was suggested as a synapomorphy of the subfamily (Muizon 1988b).

The moderately large, thick, almost triangular nasals of Mediocris commenticius most closely resemble those of Pithanodelphis cornutus. In both species, the nasals are separated almost throughout their lengths, so that only the ante- 
rior parts of the nasals meet in the midline of the skull. Nevertheless, this condition is inferred from the better preserved left side of the cranial vertex of $M$. commenticius. This situation is less specialized than the extremely inflated nasals of Atocetus (see Muizon 1988a) and Sarmatodelphis, which are in contact almost throughout their lengths.

The vertex region is incompletely known in the new species, nevertheless it is clear that the maxilla reaches to the posteriormost corner of the nasal posteriorly, indicating that the maxillae get close to the midline of the skull, similarly to, but perhaps not as much as in P. cornutus and Atocetus. In Sarmatodelphis and Leptodelphis the two maxillae expand even more medially posterior to the nasals, so that they come into contact in the midline of the skull.

The relatively large nasals, the presence of a faint internasal fossa, and the medial expansion of the posterior lobe of the maxillae relate Mediocris commenticius with members of the Pithanodelphininae. The incompleteness of the holotype and only known skull prevents the observation of other diagnostic characters of the cranial vertex. Hence, Mediocris commenticius can only tentatively be assigned to the Pithanodelphininae.

In the Delphinoidea, the foreshortening of the lumbar vertebrae is regarded as a derived feature (Muizon 1988b). Thus, the slightly elongated lumbar vertebrae of the new species are more primitive than the same elements of Atocetus nasalis and A. iquensis. On the other hand, the periotic of Mediocris commenticius is progressive in its compact appearance, in the short, mediolaterally inflected anterior process, and in the strong lateral inflection of the posterior process (for polarity of characters of the periotic see Kasuya 1973; Whitmore 1987; and Luo \& Eastman 1995).

The humerus of Mediocris commenticius is primitive in comparison to that of the Middle Miocene Atocetus iquensis from Peru and "Champsodelphis" fuchsii from the Carpathian Basin (Muizon 1988a; Kazár et al. 2004; for a comparison of kentriodontid arm bones see Kazár \& Venczel 2003). Specifically, the elongated form and the lack of distal dilatation of the humerus are regarded as primitive (Osburn 1906), because the humerus in archaeocetes is elongated, and narrower distally than proximally (e.g. Uhen \& Gingerich 2001). The deltoid tuberosity is not shifted as distally as in more advanced delphinoids (see Muizon 1988b). The maintained gap between the radius and ulna indicates that the remnants of the

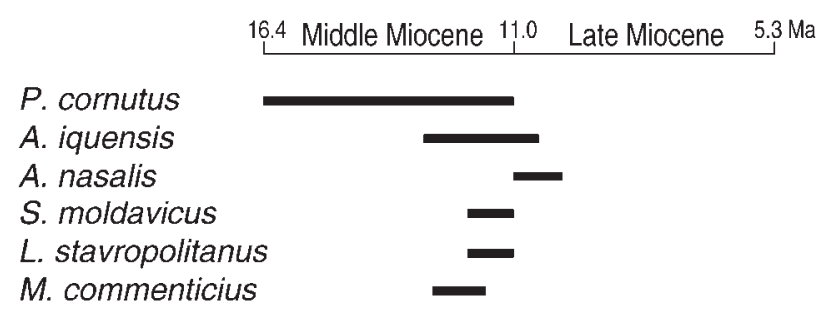

Fig. 11. Geochronological distribution of species of the Pithanodelphininae as defined by Muizon (1988a), Fordyce \& Muizon (2001), and Kazár \& Grigorescu (in press).

antebrachial muscles were retained in this species, unlike in modern delphinids and phocoenids where the radius and ulna are tightly appressed to each other. In these features, $M$. commenticius resembles Delphinodon dividum and Incacetus brog$g i$, both species grouped recently in the subfamily Kentriodontinae by Fordyce \& Muizon (2001). The manus, on the other hand, shows modern features. At least some of the phalanges are flattened, proximo-distally short and broad, similarly to the same elements of modern delphinids.

The simultaneous occurrence of primitive and derived characters suggests that $M$. commenticius is not ancestral to any of the known members of the Pithanodelphininae. The geological record shows that Mediocris commenticius is contemporaneous with Atocetus iquensis, whereas Atocetus nasalis, Leptodelphis stavropolitanus, and Sarmatodelphis moldavicus are younger (Fig. 11). The age of Pithanodelphis cornutus is problematic: Abel (1905) reported that the type horizon laid in the Boldérien Stage, and Barnes (1978, 1985, 1988) concluded that the specimen is of Late Miocene age. It should be noted, however, that the fossil remains were collected by non-professionals in the late $19^{\text {th }}$ century and therefore the exact locality and level is unknown. It was possibly found in the Antwerp Sands (O. Lambert, pers. comm. 2001) that is included in the Berchem Formation, late Early to Middle Miocene (Doppert et al. 1979; Louwye et al. 2000).

\section{Taphonomy}

The taphonomic information that exists is gained from explanations of the collectors and based on attached bones held together by the embedding matrix.

The bones of the holotype of $M$. commenticius were found partly in articulation, partly in close association (Fig. 12). The mandibles articulate with the skull. The posterior part of the right 

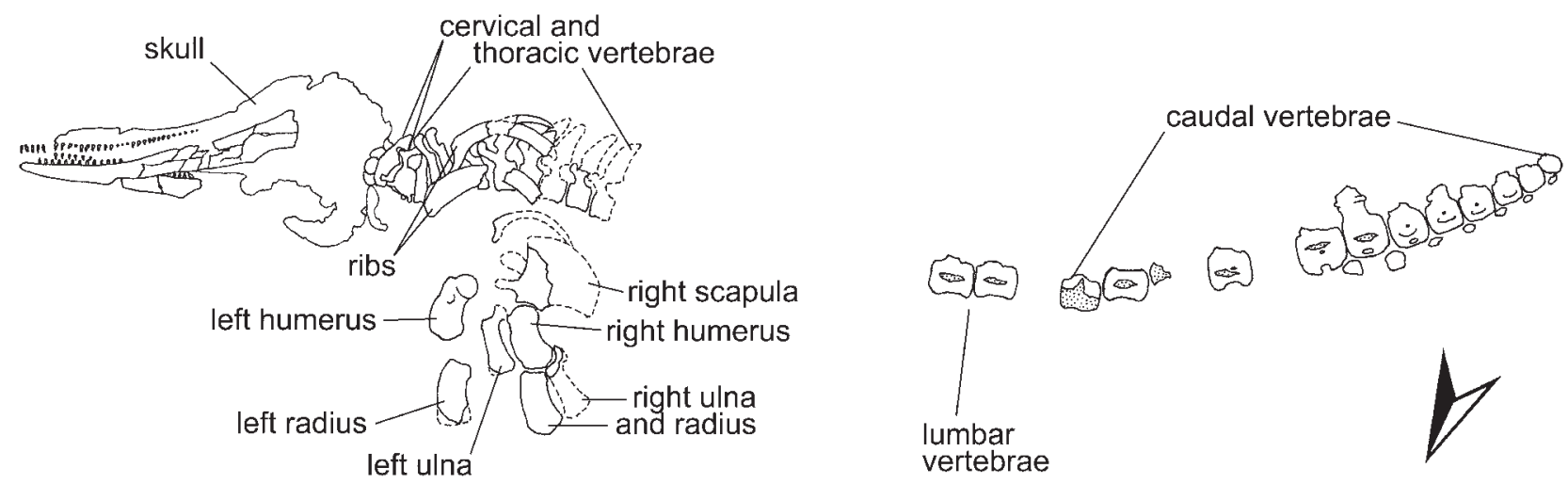

Fig. 12. Mediocris commenticius n. gen. n. sp. from Kovácsszénája, Hungary. Diagram of the skeletal elements as they were probably found. Reconstructed after discussions with the collector, Mr. S. Klaj. Without scale, North is indicated by the arrow head.

mandibular ramus was probably destroyed before burial, because an accumulation of complete posterior teeth is found behind the symphyseal part of the mandibles. Most remaining teeth sit in alveoli, but crowns of the upper right row are broken off and appressed to the left mandibular tooth row. Both auditory complexes were preserved in the skull. The left side of the dorsal surface of the skull is nearly intact, while the right side is depressed. Also, the mandibles were shifted toward the right side. The skull was found resting on its dorsal surface under the mandibles, the postcranial skeleton was lying on its right side (Figs 3, 12).

The cervical and thoracic vertebrae are only slightly dislocated. The series of articulating caudal vertebrae indicates that this region of the vertebral column was dorsally arched when buried. The caudal vertebrae remained in contact with the epiphyses of the adjacent vertebrae, but they are slightly shifted from their anatomical positions. The preserved ribs are dislocated from their articulations, and lie on top of the transverse processes of the thoracic vertebrae. A few more ribs were spread around the flippers. Both flippers were found to the northwest of the chest. The elements of the right shoulder and arm (scapula, humerus, radius and ulna) retained their articulations. Bones of the left flipper, on the other hand, were spread in the vicinity of the trunk; the left ulna was found in front of the anterior margin of the right humerus. A number of carpals, metacarpals and phalanges were found in close association with the arm bones.

The sequence of events associated with decomposition and burial of cetacean carcasses has been discussed by Schäfer (1962), Lancaster (1986), and Allison et al. (1991). It is unknown if the cadaver of the holotype of $M$. commenticius had risen to the surface and sunk after a short period of flotation, or certain factors prevented decay gases from attaining a volume sufficient to lift the body, so that the specimen was buried in place. Considering that essentially the whole skeleton underwent fossilization (the missing elements probably got lost during excavation), and a close bone-to-bone contact is maintained for most elements, the skeleton must have been well articulated when it reached the sea floor. Sufficient time must have passed between the death and the burial of the animal to attain the arch of the vertebral column.

The carcass, lying on its right side, had been partially buried by the sediment before the decomposition of the integuments resulted in the disassociation of the bones. This accounts for the fact that the elements of the right shoulder and arm retained their articulations. The left side of the carcass, however, jutted out from the sediment for longer so that the progressive decomposition of the soft tissues resulted in the displacement of the left flipper bones.

Bones of the facial region and the mandibles (especially the thin posterior part) show many irregular fracture faces indicating prefossilization breakage. Most bone surfaces are smooth and unweathered, but the premaxillae exhibit eroded surfaces in the facial region. Some of the limb bones, scapular fragments and vertebrae show slight weathering, resulting in the bone interiors being partly exposed. A few serpulid (Polychaeta) tubes were identified on a scapular fragment. The eroded surfaces and the presence of encrusting faunal elements suggest that after decomposition of the soft tissues, some skeletal elements were exposed at least for a couple of days before burial was completed. 


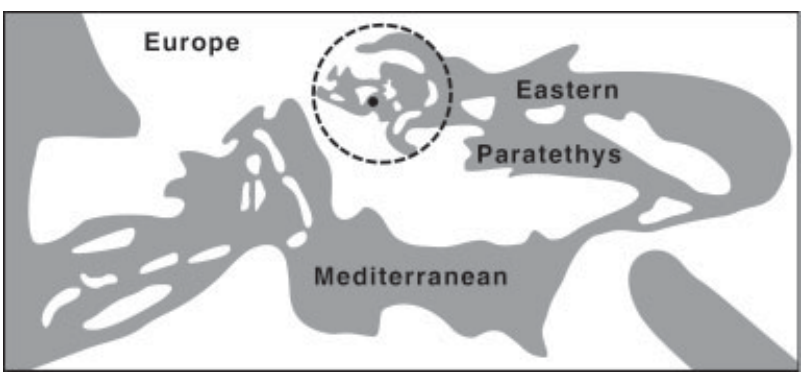

Fig. 13. The position of Kovácsszénája (black dot) within the Central Paratethys Sea (encircled area), in the early Sarmatian, late Middle Miocene. Paleogeographic reconstruction redrawn after Rögl (1998).

There are no obvious marks of predation or scavenging. The ribs found with the flipper bones were probably displaced by water motion and the posterior right mandibular teeth were washed into the space between the rami. Close association of the scattered elements attests to the fact that the cadaver was disturbed only in minor ways before complete burial.

The place of burial was a shallow sublittoral environment, as concluded from the taxonomic composition of the mollusk fauna. Epibenthic bivalves dominate among the sparse mollusk remains near the holotype skeleton (Bohn-Havas, pers. comm. 2001). The invertebrate assemblage, the presence of well-preserved small fish remains and the lack of bioturbation in the embedding marl indicate stagnant (hypoxic?) bottom waters, which may account for the undisturbed burial of the dolphin skeleton.

\section{Paleobiogeography}

Besides the holotype locality, Mediocris commenticius has been identified from two fossil sites in the Mecsek Mts., south Hungary. Both the Danitz-puszta and the Pécsvárad localities are sandpits where redeposited Badenian (Middle Miocene) and Sarmatian (late Middle Miocene) marine faunas are mixed with Pannonian (Upper Miocene) sand and its terrestrial mammal fauna (Kazár et al. 2001). The Pécsvárad sandpit is generally sparse in cetacean remains, whereas Danitz-puszta is rich in fossils. Among the odontocetes of the latter locality, $M$. commenticius is the second most abundant species in terms of the number of bones, if the most diagnostic periotics and humeri are considered (Kazár 2003 and unpublished data).

The new genus and new species is not reported from localities outside the Mecsek to date. In contrast, all other odontocete species represented in Danitz-puszta are well known from other Carpathian Basin localities as well (Kazár 2003). This raises the possibility of differences in the oceanographic conditions between the territory of the Mecsek in the South, and other parts of the Central Paratethys in the late Middle Miocene (Fig. 13), in combination with differences in the ecology of the odontocetes of the Mecsek Mts. It is well-known that the Carpathian Basin, the territory of the Central Paratethys Sea at that time, hosted various local paleohabitats during the Sarmatian (Hámor 2001).

\section{Conclusions}

Mediocris commenticius is described as a new genus, new species of the Kentriodontidae from the late Middle Miocene Sarmatian Stage of Kovácsszénája, south Hungary.

The holotype specimen, a nearly complete skeleton of a physically mature individual, was buried in shallow marine sediments of the ancient Central Paratethys Sea. A comparison with conspecific isolated periotics and humeri from Danitz-puszta, south Hungary, shows that the holotype specimen was a small individual.

The nasal bone morphology of Mediocris commenticius differs from all the known species of the Delphinoidea, but most closely resembles those of the Miocene Pithanodelphis cornutus from Belgium. The medial expansion of the posterior lobe of the maxillae, and a faint internasal fossa also indicates relationships with members of the Pithanodelphininae. Because the morphology of the cranial vertex of the new species is incompletely known, however, the assignment of Mediocris commenticius to the Pithanodelphininae remains tentative.

The lumbar and anterior caudal vertebrae of M. commenticius are not foreshortened, the humerus is more elongated as compared to the contemporaneous Atocetus iquensis. These features indicate a different (slower) swimming modus for the Hungarian species.

The paleontological record of the new species is restricted to the Mecsek Mts. in south Hungary, whereas other odontocetes known from the same localities had a much wider distribution in the Central Paratethys. 


\section{Acknowledgments}

I thank Frank C. Whitmore, Jr. (National Museum of Natural History, Washington D.C.) for all the pleasant discussions we had on odontocete evolution, and for his remarks on an earlier draft of the present paper. The critical comments of Christian de Muizon (Muséum national d'Histoire naturelle, Paris) greatly improved the manuscript. I am indebted to László Kordos (Geological Institute of Hungary, Budapest) for supporting me with every aspect of the study.

The author is grateful to Mr. Ferenc Cserpák, Mr. Árpád Dávid, Mrs. Rozália Fodor, Mr. Zoltán Evanics, Mr. Sándor Klaj, Mr. Roland Molnár, Mr. Zoltán Orbán, Mr. László Sövér and Mr. Béla Zalán for collecting material.

Thanks are due to David J. Bohaska (National Museum of Natural History, Washington D.C.), Vlad Codrea (Musée "Bassin de Transylvanie", Université "Babeş-Bolyai", ClujNapoca), Mihály Gasparik (Hungarian Natural History Museum), Stephen J. Godfrey (Calvert Marine Museum, Maryland), Dan Grigorescu (Faculty of Geology and Geophysics, University of Bucharest), Gudrun Höck (Naturhistorisches Museum Wien, Vienna), Sanja Japundžić and Jakov Radovčić (Croatian Natural History Museum, Zagreb), Olivier Lambert (Institut Royal des Sciences Naturelles de Belgique, Bruxelles), and Christian de Muizon (Muséum national d'Histoire naturelle, Paris) for facilitating access to comparative material in their care. The mollusk fauna was investigated by Margit Bohn-Havas, the micropaleontological investigations of the type section were carried out by Éva Szegó (Geological Institute of Hungary, Budapest).

The manuscript benefitted from the reviewing comments of Gloria Arratia, Oliver Hampe (Museum für Naturkunde, Zentralinstitut der Humboldt-Universität zu Berlin) and Olivier Lambert (Institut Royal des Sciences Naturelles de Belgique, Bruxelles). Financials of this study were in part covered by the Hungarian National Science Foundation (No. OTKA-T.31823) and the Bandat Horst Fund of the Geological Institute of Hungary.

\section{References}

Abel, O. 1905. Les Odontocètes du Boldérien (Miocène supérieur) d'Anvers. - Mémoires du Musée Royal d'Histoire Naturelle de Belgique, Bruxelles 3: 1-155.

Allison, P. A., Smith, C. R., Kukert, H., Deming, J. W. \& Bennett, B. A. 1991. Deep-water taphonomy of vertebrate carcasses: a whale skeleton in the bathyal Santa Catalina Basin. - Paleobiology 17: 78-89.

Barabás, A. 2001. Geological environment of the Kovácsszénája-Füstös-lik (SW-Hungary, Baranya county). - Folia Comloensis 10: 21-28. [In Hungarian, with abstract in English.]

Barnes, L. G. 1978. A review of Lophocetus and Liolithax and their relationships to the delphinoid family Kentriodontidae (Cetacea: Odontoceti). - Bulletin of the Natural History Museum of Los Angeles County 28: 1-35.

- 1984. Fossil odontocetes (Mammalia: Cetacea) from the Almejas Formation, Isla Cedros, Mexico. - Paleobios 42: $1-46$.

- 1985. The Late Miocene dolphin, Pithanodelphis Abel, 1905 (Cetacea: Kentriodontidae) from California. - Contributions in Science, Natural History Museum of Los Angeles County 367: $1-27$.

- 1988. A Late Miocene dolphin, Pithanodelphis nasalis, from Orange County, California. - Memoirs of the Natural History Foundation of Orange County 2: 7-21.

Barnes, L. G. \& Mitchell, E. 1984. Kentriodon obscurus (Kellogg, 1931), a fossil dolphin (Mammalia: Kentriodontidae) from the Miocene Sharktooth Hill Bonebed in California. - Contributions in Science, Natural History Museum of Los Angeles County 353: 1-23.
Benke, H. 1993. Investigations on the osteology and the functional morphology of the flipper of whales and dolphins (Cetacea). - Investigations on Cetacea 24: 9-252.

Bianucci, G. 2001. A new genus of kentriodontid (Cetacea: Odontoceti) from the Miocene of South Italy. - Journal of Vertebrate Paleontology 21 (3): 573-577.

Bohn-Havas, M. 2001. Fossil mollusca fauna of the outcrop at Kovácsszénája (SW-Hungary). - Folia Comloensis 10: 75-76. [In Hungarian, with abstract in English.]

Brandt, J. F. 1873. Untersuchungen über die fossilen und subfossilen Cetaceen Europa's. - Mémoires de l'Académie Impériale des Sciences de St.-Pétersbourg, $7^{\mathrm{e}}$ série 22 (1): $1-361,34 \mathrm{pls}$

Brisson, M. J. 1762. Le regnum animale in classes IX distributum, sive synopsis methodica sistens generalem animalium distributionem in classes IX, \& duarum primarum classium, quadrupedum scilicet \& cetaceorum, particularem dibvisionem in ordines, sectiones, genera \& species. 296 S., T. Haak, Paris.

Buchholtz, E. A. 2001. Vertebral osteology and swimming style in living and fossil whales (Order: Cetacea). - Journal of Zoology, London 253: 175-190.

Buchholtz, E. A. \& Schur, S. A. 2004. Vertebral osteology in Delphinidae (Cetacea). - Zoological Journal of the Linnean Society 140: 383-401.

Capellini, G. 1878. Della Pietra Leccese e di alcuni suoi fossili. - Memorie della Accademia di Scienze dell'Istituto di Bologna 9: 227-258.

Dawson, S. D. 1996a. A description of the skull and postcrania of Hadrodelphis calvertense Kellogg, 1966, and its position within the Kentriodontidae (Cetacea; Delphinoidea). Journal of Vertebrate Paleontology 16 (1): 125-134.

- 1996b. A new kentriodontid dolphin (Cetacea; Delphinoidea) from the Middle Miocene Choptank Formation, Maryland. - Journal of Vertebrate Paleontology 16 (1): 135-140.

Doppert, J. W. C., Laga, P. G. \& De Meuter F. J. 1979. Correlation of the biostratigraphy of marine neogene deposits, based on benthonic foraminifera, established in Belgium and the Netherlands. - Mededelingen Rijks Geologische Dienst 31 (1): 1-8.

Du Bus, B. 1872. Mammifères nouveaux du Crag d'Anvers. Bulletin de l'Académie Royale des Sciences, des Lettres et des Beaux-Arts de Belgique 54: 491-509.

Flower, W. H. 1867. Description of the skeleton of Inia geoffrensis and of the skull of Pontoporia blainvillii, with remarks on the systematic position of these animals in the order Cetacea. - Transactions of the Zoological Society of London 6: 87-116.

- 1870. An introduction to the osteology of the mammalia. 382 S., Macmillan \& Co., London.

Fordyce, R. E. \& Barnes, L. G. 1994. The evolutionary history of whales and dolphins. Annual Review of Earth and Planetary Sciences 22: 419-455.

Fordyce, R. E. \& de Muizon, C. 2001. Evolutionary history of cetaceans: a review. In Mazin, J.-M. \& Buffrénil, V. de (eds.): Secondary adaptation of tetrapods to life in water: 169-233, Dr. Friedrich Pfeil Verlag, München.

Fözy, I. 1993. p. 391 In Paturi, F. R.: A Föld krónikája. 576 S., Officina Nova, Budapest. (Hungarian translation from Paturi, F. R.: Chronik der Erde. Bodo Harenberg und Chronik Verlag, Dortmund 1991.)

Fraser, F. C. \& Purves, P. E. 1960. Hearing in cetaceans. Bulletin of the British Museum (Natural History), Zoology 7 (1): 1-140, pls. 1-53.

Gorjanović-Kramberger, D. 1892. O fosilnih Cetaceih Hrvatske i Kranjske. - Rada Jugoslavenske Akademije Znanosti i Umjetnosti 111: 6.

Gray, J. E. 1821. On the natural arrangement of vertebrose animals. - London Medical Repository 15 (1): 296-310.

Hámor, G. 2001. Miocene paleogeography of the Carpathian Basin. Explanatory notes to the Miocene paleogeographic maps of the Carpathian Basin 1:3000000. - Explanatory 
Notes of the Geological Institute of Hungary, Budapest, 66 pp., 4 maps, appendices 1-7.

Harlan, R. 1842. Description of a new extinct species of dolphin from Maryland. - Bulletin of the Proceedings of the National Institution for the Promotion of Science, Washington, D.C. 2: 195-196.

Harzhauser, M. \& Piller, W. E. 2004. The Early Sarmatian and hidden seaway changes. - Courier Forschungsinstitut Senckenberg 246: 89-112.

Ichishima, H., Barnes, L. G., Fordyce, R. E., Kimura, M. \& Bohaska, D. J. 1994. A review of kentriodontine dolphins (Cetacea; Delphinoidea; Kentriodontidae): Systematics and biogeography. - The Island Arc 3: 486-492.

Kasuya, T. 1973. Systematic consideration of recent toothed whales based on the morphology of tympano-periotic bone. - The Scientific Reports of the Whales Research Institute 25: 1-103.

Kazár, E. 2003. Miocén fogascet-leletek (Cetacea: Odontoceti) a Kárpát-medencében. [Miocene toothed whales (Cetacea: Odontoceti) in the Carpathian Basin.] Ph.D. thesis, 344 S., Eötvös Loránd University, Budapest. [In Hungarian, with abstract in English.]

- 2005. A mecseki fogascetek. [Middle Miocene toothed whales (Cetacea: Odontoceti) in the Mecsek (Baranya County, South Hungary)] In Fazekas, I. (ed). A komlói térség természeti és kultúrtörténeti öröksége: 91-110, RegioGRAFO Bt., Komló. [In Hungarian, with abstract in English.]

Kazár, E. \& Grigorescu, D. in press. Revision of Sarmatodelphis moldavicus Kirpichnikov, 1954 (Cetacea: Delphinoidea) from the Miocene of Kishinev, Republic of Moldavia. - Journal of Vertebrate Paleontology.

Kazár, E. \& Kordos, L. 1999. Neogene cetacean fauna of the Carpathian Basin: A review. - European Research on Cetaceans 12: 313-317.

Kazár, E. \& Venczel, M. 2003. Kentriodontid remains (Cetacea: Odontoceti) from the Middle Miocene of the of $\mathrm{Bi}$ hor County, Romania. - Nymphaea, Folia naturae Bihariae 30: 39-66.

Kazár, E., Kordos, L. \& Szónoky, M. 2001. Danitz-pusztai homokbánya. Pannon homok áthalmozott ősgerincesmaradványokkal. [Age of the toothed whale fauna from Danitz-puszta (Pécs).] - Excursion Guide, Magyarhoni Földtani Társulat Ôslénytani-Rétegtani Szakosztály, Budapest, pp. 42-43. [In Hungarian.]

Kazár, E., Vremir, M. \& Codrea, V. 2004. Dolphin remains (Cetacea: Odontoceti) from the Middle Miocene of ClujNapoca, Romania. - Acta Palaeontologica Romaniae (V. Codrea, Petrescu, I. \& Dica, P. eds.) 4: 179-189.

Kellogg, R. 1925a. The relationships of the Tertiary cetaceans of Jugo-Slavia to those of eastern North America. - Exemplar E Xeniis Goranjović-Krambergerianis, Zagreb, $1-8$.

- 1925b. On the occurrence of remains of fossil porpoises of the genus Eurhinodelphis in North America. - Proceedings of the United States National Museum 66 (26): 1-40.

- 1927. Kentriodon pernix, a Miocene porpoise from Maryland. - Proceedings of the United States National Museum 69 (19): 1-55.

- 1931. Pelagic mammals from the Temblor Formation of the Kern River region, California. - Proceedings of the California Academy of Sciences, Ser. 419 (12): 217-397.

- 1955. Three Miocene porpoises from the Calvert Cliffs, Maryland. - Proceedings of the United States National Museum 105: 101-154.

- 1966. A new odontocete from the Calvert Miocene of Maryland. - Bulletin of the United States National Museum of Natural History 247: 99-101.

Kirpichnikov, A. A. 1954. Two new dolphin genera from the Sarmatian of the USSR. - Akademiya Nauki SSSR, Trudy Paleontologitseskogo Instituta 47: 181-193.

Lancaster, W. C. 1986. The taphonomy of an archaeocete skeleton and its associated fauna. - Gulf Coast Association of Geological Society Publications 119: 119-131.
Louwye, S., De Coninck, J., \& Verniers, J. 2000. Shallow marine Lower and Middle Miocene deposits at the southern margin of the North Sea Basin (northern Belgium): dinoflagellate cyst biostratigraphy and depositional history. Geological Magazine 137 (4): 381-394.

Luo, Zhe-Xi \& Eastman, E. R. 1995. Petrosal and inner ear of a squalodontid whale: implications for evolution of hearing in odontocetes. - Journal of Vertebrate Paleontology 15 (2): 431-442.

Luo Zhe-Xi \& Marsh, K. 1996. Petrosal (periotic) and inner ear of a Pliocene kogiine whale (Kogiinae, Odontoceti): implications on relationships and hearing evolution of toothed whales. - Journal of Vertebrate Paleontology 16 (2): $328-348$.

Mead, J. G. 1975. Anatomy of the external nasal passages and facial complex in the Delphinidae (Mammalia: Cetacea). - Smithsonian Contributions to Zoology 207: $1-72$.

de Muizon, C. 1985. Nouvelles données sur le diphylétisme des Dauphins de rivière (Odontoceti, Cetacea, Mammalia). - Comptes rendus de l'Académie des Sciences, Paris, 2e sér. 301 (5): 359-362.

- 1988a. Les vertébrés fossiles de la Formation Pisco (Pérou) III. Les Odontocètes (Cetacea, Mammalia) du Miocène. - Travaux de l'I.F.E.A., 42, Mémoire n 78: 1-244.

- 1988b. Les relations phylogénétiques des Delphinida (Cetacea, Mammalia). - Annales de Paléontologie 74 (4): 159-227.

- 1993. Walrus-like feeding adaptation in a new cetacean from the Pliocene of Peru. Nature 365: 745-748.

Osburn, R. C. 1906. Adaptive modifications of the limb skeleton in aquatic reptiles and mammals. - Annals of the New York Academy of Sciences 16 (3): 447-476.

Perrin, W. F. 1975. Variation of spotted and spinner porpoise (genus Stenella) in the Eastern Pacific and Hawaii. - Bulletin of the Scripps Institution of Oceanography 21: 1206.

Rensberger, J. M. 1969. A new iniid cetacean from the Miocene of California. - University of California Publications in Geological Sciences 82: 1-34.

Rice, D. W. 1998. Marine Mammals of the World. Systematics and distribution. - Special Publications of the Society for Marine Mammalogy 4: 1-231.

Rommel, S. A. 1990. Osteology of the bottlenose dolphin. In Leatherwood, S. \& Reeves, R. R. (eds.): The bottlenose dolphin: 29-49, Academic Press, San Diego, CA.

Rögl, F. 1998. Palaeogeographic considerations for Mediterranean and Paratethys seaways (Oligocene to Miocene). - Annalen des Naturhistorischen Museums in Wien 99A: 279-310.

Schäfer, W. 1962. Aktuo-Paläontologie nach Studien in der Nordsee. 666 S., Waldemar Kramer, Frankfurt a. M.

Slijper, E. J. 1936. Die Cetaceen vergleichend-anatomisch und systematisch. - Capita Zoologica 7: 1-590.

Sütő-Szentai, M. 2001. Organic-walled microplancton studies at Kovácsszénája (S-Hungary). - Folia Comloensis 10: 29-38. [In Hungarian, with abstract in English.]

Szegó, É. \& Szuromi-Korecz, A. 2001. Data for the knowledge of foraminifera and ostracoda microfauna of Kovácsszénája (SW-Hungary). - Folia Comloensis 10: 5174. [In Hungarian, with abstract in English.]

True, F. W. 1912. Description of a new fossil porpoise of the genus Delphinodon from the Miocene Formation of Maryland. - Journal of the Academy of Natural Sciences of Philadelphia $2^{\text {nd }}$ ser. 15: $165-194$

Uhen, M. D. \& Gingerich, P. D. 2001. New genus of dorudontine archaeocete (Cetacea) from the middle-to-late Eocene of South Carolina. - Marine Mammal Science 17 (1): 1-34.

Whitmore Jr., F. C. 1987. A delphinoid ear bone from the Dam Formation (Miocene) of Saudi Arabia. - Bulletin of the British Museum of Natural History (Geology) 41 (4): $447-450$. 